\title{
Sex steroid-producing enzymes in human breast cancer
}

\author{
Takashi Suzuki, Yasuhiro Miki, Yasuhiro Nakamura, Takuya Moriya, \\ Kiyoshi Ito ${ }^{7}$, Noriaki Ohuchi ${ }^{2}$ and Hironobu Sasano
}

Departments of Pathology, ${ }^{1}$ Obstetrics and Gynecology and ${ }^{2}$ Surgical Oncology, Tohoku University School of Medicine, 2-1 Seiryo-machi, Aoba-ku, Sendai, 980-8575, Japan

(Requests for offprints should be addressed to H Sasano; Email: hsasano@patholo2.med.tohoku.ac.jp)

\begin{abstract}
It is well known that sex steroids are involved in the growth of breast cancers, and the great majority of breast carcinomas express estrogen (ER), progesterone (PR), and androgen (AR) receptors. In particular, recent studies have demonstrated that estrogens and androgens are locally produced in breast carcinoma tissues, and total blockade of in situ estrogen production potentially leads to an improvement in prognosis of breast cancer patients. Therefore, it is important to obtain a better understanding of sex steroid-producing enzymes in breast carcinoma tissues. In this review, we summarize recent studies on the expression and regulation of enzymes related to intratumoral production of estrogens (aromatase, 17 $\beta$-hydroxysteroid dehydrogenase type 1 (17ßHSD1), and steroid sulfatase (STS) etc) and androgens (17ßHSD5 and $5 \alpha$-reductase) in human breast carcinoma tissues, and discuss the biological and/or clinical significance of these enzymes. The cellular localization of aromatase in breast carcinoma tissues still remains controversial. Therefore, we examined localization of aromatase mRNA in breast carcinoma tissues by laser capture microdissection/real time-polymerase chain reaction. Aromatase mRNA expression was detected in both carcinoma and intratumoral stromal cells, and the expression level of aromatase mRNA was higher in intratumoral stromal cells than in carcinoma cells in the cases examined. We also examined an association among the immunoreactivity of enzymes related to intratumoral estrogen production and ERs in breast carcinoma tissues, but no significant association was detected. Therefore, the enzymes responsible for the intratumoral production of estrogen may not always be the same among breast cancer patients, and not only aromatase but also other enzymes such as STS and $17 \beta \mathrm{HSD} 1$ may have important therapeutic potential as targets for endocrine therapy in breast cancer patients.
\end{abstract}

Endocrine-Related Cancer (2005) 12 701-720

\section{Introduction}

Biologically active hormones are produced and secreted from the endocrine organs, transported through the circulation, and act on their target tissues where their specific receptors are expressed (Fig. 1A). This system is known as the endocrine system, and biological features of hormone-dependent target tissues are generally considered to be influenced by the plasma concentration of the biologically active hormones. In addition, hormones can also act in the same cell (autocrine) (Fig. 1B) or neighboring cells (paracrine) (Fig. 1C) without release into the circulation. A large proportion of androgens in men (approximately 50\%) and estrogens in women (approximately $75 \%$ before the menopause, and close to $100 \%$ after the menopause) are synthesized in peripheral hormone-target tissues from abundantly present circulating precursor steroids (Labrie et al. 2003), where the enzymes involved in the formation of androgens and estrogens are expressed (Fig. 1D). These locally produced bioactive androgens and/or estrogens exert their action in the cells where synthesis occurs without release into the extracellular space. This phenomenon is different from the autocrine, paracrine and classical endocrine action, and is called intracrine'. In classical endocrine systems, only a small amount of hormone is generally utilized in the target tissues, and thereafter the great majority is metabolized or converted to inactive forms. On the other hand, 
A

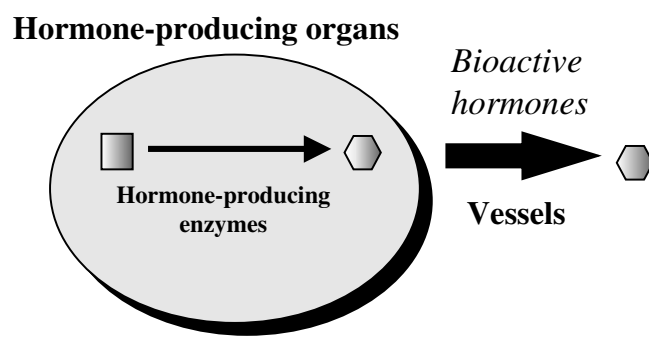

Hormone-target tissues

B

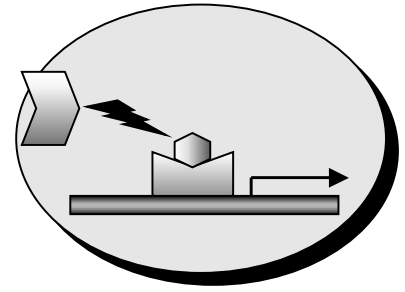

C

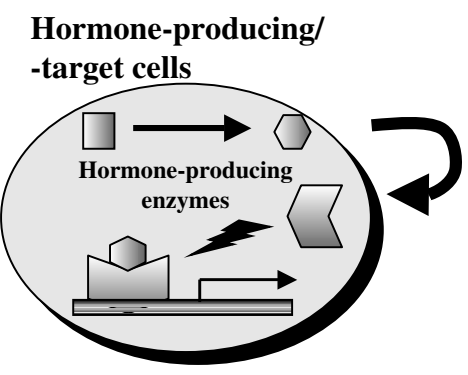

Hormone-producing cells

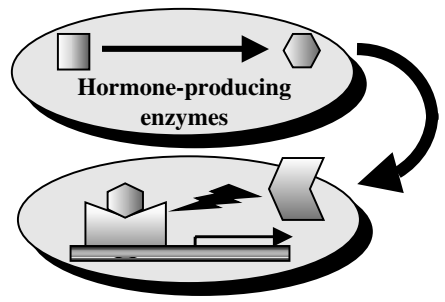

Hormone-target cells

D

Hormone-producing organs

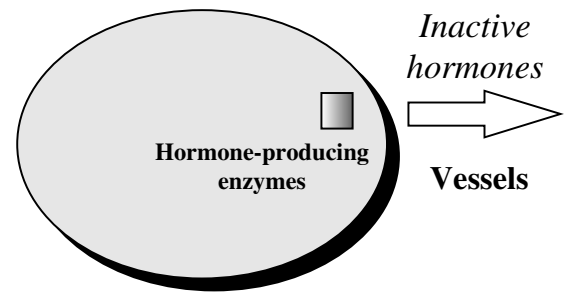

Hormone-target tissues

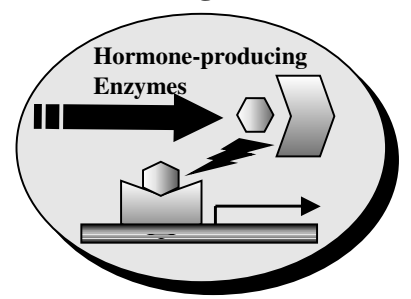

Figure 1 Summary of endocrine (A), autocrine (B), paracrine (C), and intracrine (D) actions. $\square$, inactive hormone; $\square$, bioactive hormone; $\square$, receptor; $\square$, promoter region of the target gene.

an intracrine system requires minimal amounts of biologically active hormones to exert their maximum effects. Therefore, intracrine is an efficient mode of hormone action and plays important roles especially in the development of hormone-dependent neoplasms. It is also important to note that, in an intracrine system, serum concentrations of hormones do not necessarily reflect the local hormonal activity in the target tissues.

Sex steroids, such as estrogens and androgens, play important roles in various target tissues including reproductive organs. A majority of breast carcinoma tissues express estrogen (ER) and androgen (AR) receptors, and estrogens greatly contribute to the growth of breast cancers. Breast carcinoma tissues have been demonstrated to process intracrine activity. Locally produced biologically active estrogens act in breast carcinoma tissues. This mechanism has been considered to play a pivotal role in the proliferation of breast carcinoma cells. The blockade of this pathway potentially reduces cell proliferation of breast tumors, and it is very important to obtain a better understanding of sex steroid-related enzymes in breast carcinoma as potential therapeutic targets of endocrine therapy. Therefore, in this review we summarize the results of recent studies on the expression and regulation of the enzymes related to intratumoral production of sex steroids in human breast carcinoma tissues, and discuss the potential biological and/or clinical significance of intratumoral production of sex steroids in these carcinomas.

\section{Intratumoral production of estrogens in breast carcinoma tissue}

Circulating estrogens are mainly secreted from the ovary in premenopausal women. However, after the 


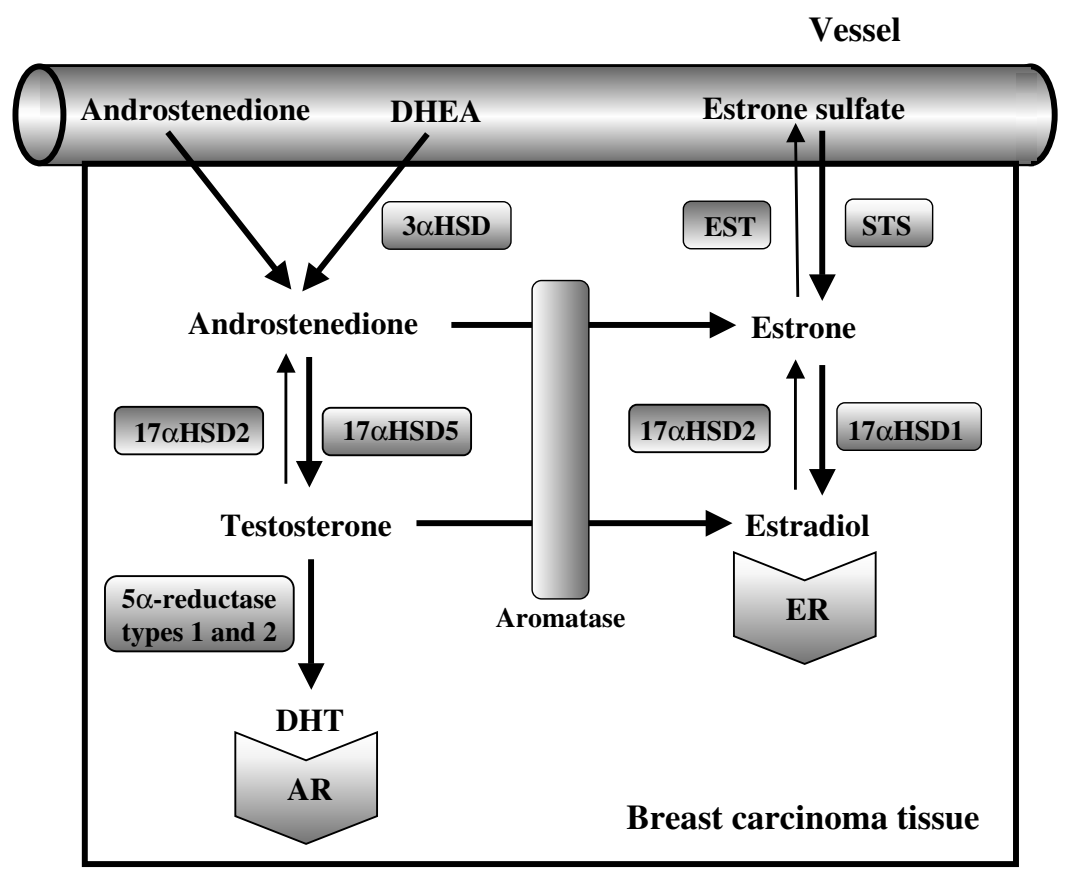

Figure 2 Scheme representing local production of sex steroids in human breast carcinoma tissues. High concentrations of circulating inactive steroids, such as androsteonedione, dehydroepiandrosterone (DHEA) and estrone sulfate, are precursor substrates of local production of estrogens and/or androgens in breast carcinomas. Bioactive sex steroids, estradiol and $5 \alpha$-dihydrotestosterone (DHT) are locally produced and act on the carcinoma cells through estrogen (ER) and androgen (AR)

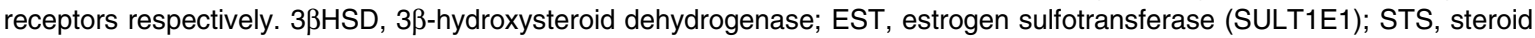
sulfatase; $17 \beta \mathrm{HSD}$, 17 $\beta$-hydroxysteroid dehydrogenase.

menopause, estrogens are biosynthesized in peripheral tissues such as adipose tissue, skin, and muscle, through conversion of circulating inactive steroids (Sasano \& Harada 1998). Intratumoral estradiol levels were not significantly different between premenopausal and postmenopausal breast cancer patients, but the intratumoral estradiol/estrone ratio was significantly higher in postmenopausal than in premenopausal breast cancers (Miyoshi et al. 2001). The ratio of estradiol concentration in tumor tissue/plasma was 23 in postmenopausal breast carcinomas, but was 5 in premenopausal breast carcinomas (Pasqualini et al. 1996, Pasqualini 2004). In addition, the concentration of estradiol was 2.3-times higher in breast cancer tissues than in the areas considered as morphologically normal (Chetrite et al. 2000). The great majority of breast cancers occur after the menopause and express ER, which suggests that the in situ production of estrogens plays an important role in the proliferation of breast cancer cells, especially in postmenopausal women.

Figure 2 summarizes the representative pathways of in situ production of sex steroids in human breast carcinoma tissues, which are currently postulated.
High concentrations of circulating inactive steroids, such as androsteonedione and estrone sulfate, are considered major precursor substrates of local estrogen production. Briefly, aromatase catalyzes androstenedione into estrone, while steroid sulfatase (STS) hydrolyzes estrone sulfate to estrone. Estrone is subsequently converted to estradiol by $17 \beta$-hydroxysteroid dehydrogenase type 1 (17ßHSD1), and locally acts on breast cancer cells through ER. Therefore, it becomes very important to examine these enzymes in human breast carcinomas in order to obtain a better understanding of the local actions of estrogen. Several other enzymes are also known to be involved in the regulation of local estrogen production (Fig. 2).

\section{Aromatase}

Aromatase (CYP19) is an enzyme located in the endoplasmic reticulum of estrogen producing cells, and is a key enzyme in the synthesis of estrogens, mainly aromatization of androstenedione to estrone (Fig. 2). In $63-72 \%$ of breast carcinoma specimens aromatase activity was comparable with or greater than that found in other tissues (Silva et al. 1989, 
Miller et al. 1990, Miller 1991, Lipton et al. 1992, Bolufer et al. 1992). Aromatase activity was higher in the stromal than in the epithelial component in breast tumors (Purohit et al. 1995), but aromatase activity was also detected in several breast carcinoma cell lines (Kinoshita \& Chen 2003, Sonne-Hansen \& Lykkesfeldt 2005). Positive correlations were reported between aromatase activity and ER (Miller et al. 1990, Miller 1991) or tumor grade (Silva et al. 1989). However, results of these studies have not necessarily been confirmed by other groups, and no consistent correlations between these two parameters have been established (de Jong et al. 2001). In addition, no significant association between aromatase activity and disease-free interval or overall survival has been reported. The level of aromatase mRNA expression was highest in a quadrant bearing carcinoma among four breast quadrants of mastectomy (Bulun et al. 1993), and aromatase mRNA levels in breast carcinomas were significantly increased compared with those in non-malignant tissues (Utsumi et al. 1996), which was consistent with the reported findings of aromatase activity in breast cancers described above. In order to examine the localization of aromatase mRNA in breast carcinoma tissues, we examined laser capture microdissection/real time-polymerase chain reaction ( $\mathrm{LCM} /$ real-time $\mathrm{PCR}$ ) for aromatase in breast carcinoma tissues (Fig. 3A). As shown in Fig. 3B, mRNA expression of aromatase was detected in both carcinoma and intratumoral stromal cells adjacent to the carcinoma cells. The level of aromatase mRNA expression was significantly $(P=0.0040)$ higher in intratumoral stromal cells than in carcinoma cells (Fig. 3C), and no significant association was detected in aromatase mRNA expression between intratumoral stromal cells and carcinoma cells (data not shown). Immunolocalization of aromatase was examined by several groups, but reported results of aromatase immunolocalization in breast cancers appear to be inconsistent (Table 1). Previously, Sasano et al. (1994) demonstrated aromatase immunoreactivity in stromal cells such as intratumoral fibroblasts (Fig. 4A) and adipocytes in breast carcinoma tissues. Santen et al. (1994) also demonstrated aromatase immunoreactivity predominantly in the stromal cells, On the other hand, Esteban et al. (1992), Lu et al. (1996) and Brodie et al. (2001) reported aromatase immunoreactivity in breast carcinoma cells. Shenton et al. (1998) examined two different antibodies for aromatase in breast carcinomas, and reported the different cellular immunolocalization. Recently, Sasano et al. (2003) validated several new aromatase antibodies for immunohistochemistry, and demonstrated that aromatase immunoreactivity was detected in various types of cells such as stromal cells, carcinoma cells (Fig. 4B) and normal duct epithelial cells. These discrepant results of aromatase immunolocalization in previous studies may be due to the different nature of the aromatase antibodies employed. Esteban et al. (1992) reported an inverse association between aromatase immunoreactivity and ER status in breast cancers, but no consistent correlations between aromatase immunoreactivity and known clinicopathological factors have been reported. Further investigations are required for clarification.

In addition, it remains unclear by which mechanism aromatase expression is increased in breast carcinoma tissues. Breast carcinoma cells secrete various factors that induce aromatase expression in adipose fibroblasts (Zhou et al. 2001), and the regulation of aromatase expression is partly considered as tumorstromal interactions. For instance, prostaglandin $\mathrm{E}_{2} \quad\left(\mathrm{PGE}_{2}\right)$ produced from breast carcinoma cells markedly stimulates aromatase expression in adipostromal cells (Zhao et al. 1996, Singh et al. 1999), and $\mathrm{PGE}_{2}$ production was partly regulated by estrogenic actions (Frasor et al. 2003). Various cytokines, such as interleukin (IL)-1, IL-6, IL-11 and tumor necrosis factor (TNF)- $\alpha$ (Reed \& Purohit 2001, Simpson \& Davis 2001), which are released from carcinoma cells and/or inflammatory cells were also demonstrated to be capable of significant induction of aromatase expression in breast cancers.

Previous studies also demonstrated the regulation of aromatase expression by various transcriptional factors. Transcription of aromatase is activated by steroidogenic factor 1 (SF1; designated NR5A1) in the ovary, which binds to a nuclear receptor half site (NRE) within their promoter regions to mediate basal transcription and, in part, cAMP-induced transcription (Parker \& Schimmer 1997). However, SF1 is not expressed in breast carcinoma tissues (Clyne et al. 2002). Clyne and colleagues also examined various orphan nuclear receptors known to bind to such an NRE in 3T3-L1 preadipocytes, and reported the induction of aromatase expression by liver receptor homologue-1 (LRH-1; NR5A2) in the adipose stromal cells in breast cancers (Clyne et al. 2002, Zhou et al. 2005). Significant association was detected between LRH-1 and aromatase mRNA levels in the adipose tissues adjacent to the carcinoma, but not in the breast carcinoma tissues (Zhou et al. 2005), suggesting that LRH-1 may mainly regulate aromatase expression in adipose tissue adjacent to the breast carcinoma. Induction of aromatase expression by CCAAT/enhancer binding protein 
A
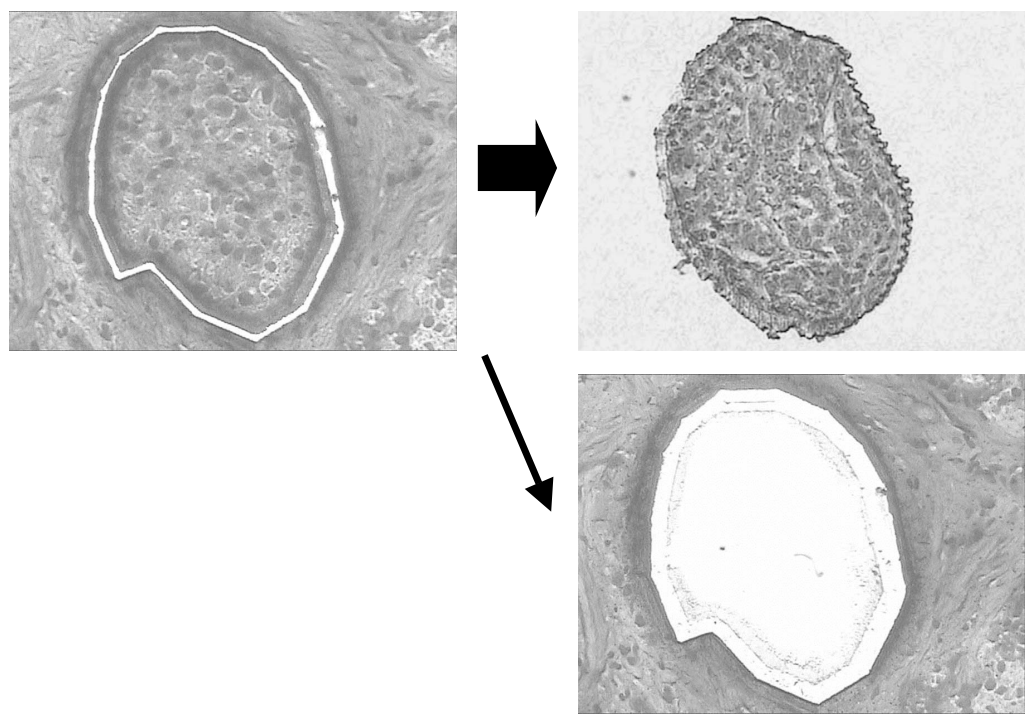

B

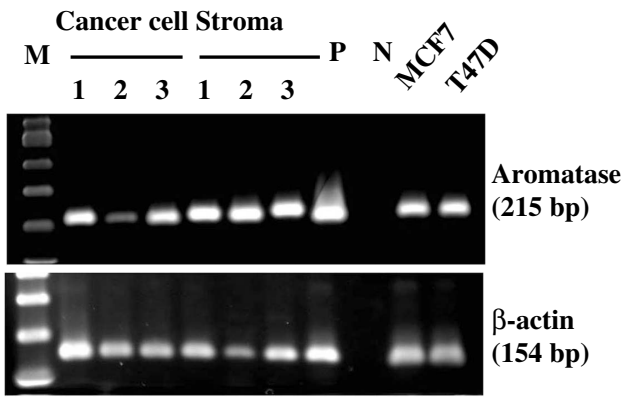

C

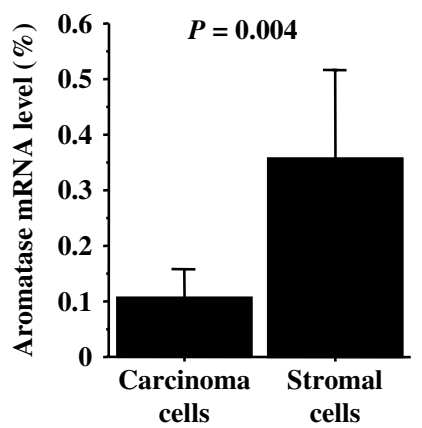

Figure 3 LCM/real-time PCR for aromatase in breast carcinoma tissues. (A) Representation of LCM. A nest of carcinoma cells was dissected from breast carcinoma frozen tissues under a microscope using Laser Scissors CRI-337 (Cell Robotics Inc, Albuquerque, NM, USA) (left panel), and was separately collected (right upper panel). The residual tissue is shown in the right lower panel. (B) Localization of aromatase mRNA in breast carcinoma tissues. Expression of aromatase mRNA was detected both in carcinoma and intratumoral stromal cells. Aromatase mRNA was also detected in MCF7 and T47D breast carcinoma cells. $\mathrm{P}$, positive control (human placental tissue); $\mathrm{N}$, negative control (no cDNA substrate); $\mathrm{M}$, molecular marker. About 1000 carcinoma or intratumoral stromal cells were collected separately using LCM as shown in A, and real-time PCR was performed using a Light Cycler System (Roche Diagnostics). PCR was performed for 40 cycles, and three representative cases of breast carcinoma tissues and two breast carcinoma cell lines (MCF7 and T47D) were represented in this agarose gel photo. PCR for $\beta$-actin was also performed as an internal control. (C) Cellular expression of aromatase mRNA in breast carcinoma tissues. Expression levels of aromatase mRNA were significantly (3.5-times; $P=0.004)$ higher in intratumoral stromal cells than in breast carcinoma cells. Data are presented as means $\pm 95 \%$ confidence interval $(n=12)$. The expression level of aromatase mRNA in each sample has been summarized as a ratio of $\beta$-actin, and subsequently evaluated as a ratio (\%) compared with that of the positive control (human placental tissue).

$(\mathrm{C} / \mathrm{EBP})$ was also reported in adipose fibroblasts in breast cancer (Zhou et al. 2001). On the other hand, estrogen-related receptor- $\alpha$ (ERR $\alpha$; NR3B1), which was mainly immunolocalized in breast cancer cells (Suzuki et al. 2004), had a positive regulatory function on aromatase in SK-BR-3 breast cancer cells (Yang et al. 1998), but not in 3T3-L1 preadipocytes
(Clyne et al. 2002). In addition, Sebastian et al. (2002) reported up-regulation of aromatase by GATA-2 in vascular endothelial cells of breast cancer. Therefore, aromatase expression is possibly regulated by various transcriptional factors in breast cancer tissues, and the key regulator may be different according to the types of cells in breast carcinoma tissues. 
Table 1 Summary of previous studies for aromatase immunolocalization in breast carcinoma tissues

\begin{tabular}{|c|c|c|c|}
\hline Study & Characteristics of antibody & Pretreatment & Predominant localization \\
\hline Esteban et al. 1992 & Rabbit polyclonal & Trypsin & Carcinoma cells \\
\hline Sasano et al. 1994 & $\begin{array}{l}\text { Rabbit polyclonal } \\
\text { (provided by Dr N Harada) }\end{array}$ & None & Stromal cells \\
\hline Santen et al. 1994 & $\begin{array}{l}\text { Rabbit polyclonal } \\
\text { (provided by Dr N Harada) }\end{array}$ & None & $\begin{array}{l}\text { Stromal }>\text { carcinoma cells } \\
\text { and normal breast elements }\end{array}$ \\
\hline Lu et al. 1996 & $\begin{array}{l}\text { Mouse monoclonal } \\
\text { (provided by Dr E Simpson) }\end{array}$ & Microwave & Carcinoma $>$ stromal cells \\
\hline \multirow[t]{2}{*}{ Shenton et al. 1998} & $\begin{array}{l}\text { Mouse monoclonal } \\
\text { (provided by Dr E Simpson) }\end{array}$ & Microwave & $\begin{array}{l}\text { Carcinoma and } \\
\text { stromal cells }\end{array}$ \\
\hline & $\begin{array}{l}\text { Rabbit polyclonal } \\
\text { (provided by Dr N Harada) }\end{array}$ & None & Stromal cells \\
\hline Brodie et al. 2001 & $\begin{array}{l}\text { Mouse monoclonal } \\
\text { (provided by Dr E Simpson) }\end{array}$ & Microwave & Carcinoma cells \\
\hline \multirow[t]{2}{*}{ Sasano et al. 2003} & Mouse monoclonal (677) & None & $\begin{array}{l}\text { Stromal, carcinoma, } \\
\text { and normal epithelial cells }\end{array}$ \\
\hline & Mouse monoclonal (F2) & Autoclave & $\begin{array}{l}\text { Stromal, carcinoma, } \\
\text { and normal epithelial cells }\end{array}$ \\
\hline
\end{tabular}

\section{7ßHSD1 and 17ßHSD2}

$17 \beta H S D$ catalyzes an interconversion of estrogens or androgens. To date, 12 isozymes of $17 \beta$ HSD have been

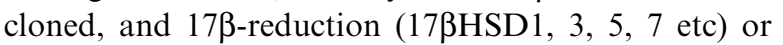
oxidation (17ßHSD2, 4, 6 etc) of estrogens and/ or androgens is catalyzed by different $17 \beta \mathrm{HSD}$ isozymes. Among these isozymes, 17ßHSD1 enzyme uses NADPH as a cofactor, and is considered mainly to catalyze the reduction of estrone to estradiol (Peltoketo et al. 1988, Luu-The et al. 1989). On the other hand, the 17ßHSD2 enzyme uses NAD+ as a cofactor, and catalyzes the oxidation of both estradiol to estrone and testosterone to androstenedione ( $\mathrm{Wu}$ et al. 1993) (Fig. 2). Oxidative 17ßHSD activity is the preferential direction in normal breast tissues, but the reductive $17 \beta$ HSD pathway is dominant in breast cancers (Speirs et al. 1998, Miettinen et al. 1999). Miyoshi et al. (2001) reported that the intratumoral estradiol/estrone ratio was significantly higher in postmenopausal than in premenopausal breast cancers, and is suggestive of the relative importance of 17ßHSD reductive activity in the maintenance of high intratumoral estradiol levels in postmenopausal patients. In hormone-dependent breast cancer cell lines, such as MCF7, T47D, R-27, and ZR75-1, 17ßHSD1 was the predominant reductive isoform, while oxidative $17 \beta$ HSD activity was the preferential enzymatic orientation in hormone-independent breast cancer cell lines such as MDA-MB-231, NDA-MB-436, and Hs-578S (Pasqualini 2004).

Both 17ßHSD1 and 17ßHSD2 mRNA expression was detected in normal mammary glands (Gunnarsson et al. 2001), and oxidative 17ßHSD activity is postulated to be due to 17ßHSD2 (Miettinen et al. 1999). In breast carcinomas, Miyoshi et al. (2001) reported that 17ßHSD1 mRNA levels were significantly higher in postmenopausal than in premenopausal breast cancer tissue specimens. They suggested an association between up-regulation of 17ßHSD1 and intratumoral estradiol levels in postmenopausal patients. Gunnarsson et al. (2001) also demonstrated that breast cancer patients with high levels of $17 \beta H S D 1$ mRNA or loss of $17 \beta H S D 2$ mRNA expression were associated with increased risk of developing a late relapse of breast cancer.

Both 17ßHSD1 and 17ßHSD2 immunoreactivity was focally detected in the epithelium of normal mammary glands (Ariga et al. 2000). In breast cancers, 17ßHSD1 immunoreactivity was detected in carcinoma cells in 47-61\% of cases (Poutanen et al. 1992a, Sasano et al. 1996, Suzuki et al. 2000a) (Fig. 4C) (Table 2). Suzuki et al. (2000a) reported that 17ßHSD1 immunoreactivity was significantly correlated with $\mathrm{ER} \alpha$ and progesterone receptor (PR), and inversely associated with histological grade and Ki67. No significant association was reported between 17ßHSD1 immunoreactivity and menopausal status in breast cancers in these previous reports, although Miyoshi et al. (2001) reported this correlation employing quantitative real-time PCR. This discrepancy may partly be due to the fact that immunohistochemical results do not necessarily reflect the protein amount. Suzuki et al. (2000a) reported no 17ßHSD2 immunoreactivity in 111 breast carcinoma tissues examined. 

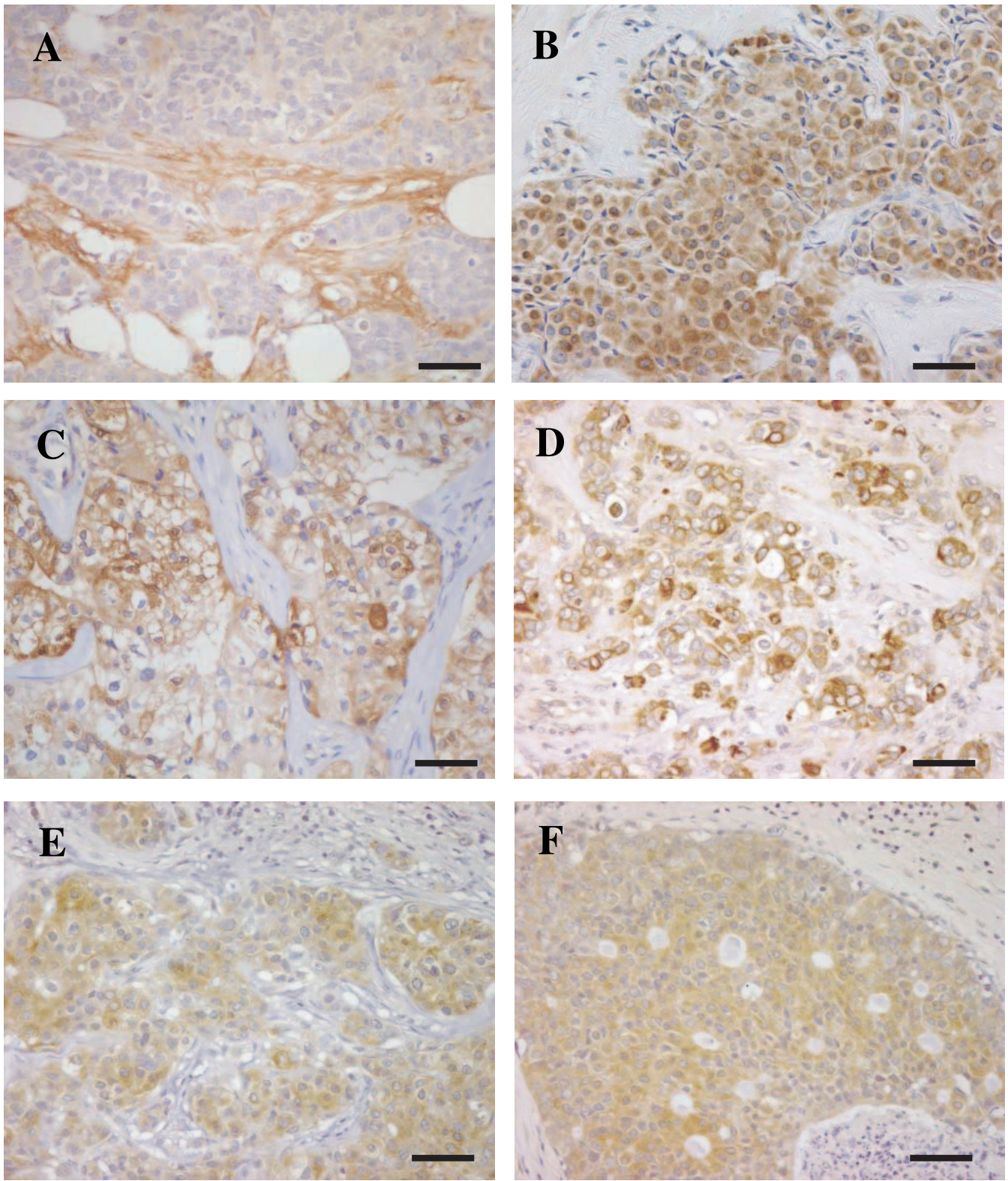

Figure 4 Immunolocalization of sex-steroid producing enzymes in breast carcinoma tissue. (A) Aromatase immunoreactivity was detected in the cytoplasm of stromal cells adjacent to the carcinoma cells when the rabbit polyclonal antibody kindly provided by Dr N Harada (same antibody as used by Sasano et al. 1994) was used. (B) On the other hand, aromatase immunoreactivity was also detected in the cytoplasm of carcinoma cells when the mouse monoclonal (677) was used (same antibody as used by Sasano et al. 2003). (C-F) Immunohistochemistry for 17ßHSD1 (C), STS (D), 17ßHSD5 (E) and $5 \alpha$-reductase type $1(F)$ in breast carcinoma. Immunoreactivity for these enzymes was observed in the cytoplasm of carcinoma cells. Bars $=50 \mu \mathrm{m}$.

The gene coding for 17ßHSD1 (HSD17B1) is located at $17 \mathrm{q} 12-21$, and frequent genetic rearrangement is known in this region (Kauraniemi et al. 2001). Recently, Gunnarsson et al. (2003) detected amplification of HSD17B1 in $32(15 \%)$ out of 221 postmenopausal breast cancers. This gene amplification was related to decreased breast cancer survival for ER-positive patients who received adjuvant tamoxifen. Gunnarsson et al. (2003) also demonstrated that some carcinomas without HSD17B1 amplification expressed 17ßHSD1 mRNA at high levels, suggesting other regulatory mechanisms for $17 \beta \mathrm{HSD} 1 \mathrm{mRNA}$ 
Table 2 Summary of immunohistochemical analysis of $17 \alpha \mathrm{HSD} 1$ in breast carcinoma tissues

\begin{tabular}{|c|c|c|c|}
\hline Study & $\begin{array}{l}\text { No. of cases } \\
\text { examined }\end{array}$ & $\begin{array}{l}\% \text { of } 17 \alpha \mathrm{HSD} 1 \\
\text { positive cases }\end{array}$ & $\begin{array}{c}\text { Association between } 17 \alpha \mathrm{HSD} 1 \text { immunoreactivity } \\
\text { and clinicopathological parameters }\end{array}$ \\
\hline Poutanen et al. $1992 a$ & 34 & $47 \%$ & Positive association: PR \\
\hline Sasano et al. 1996 & 41 & $56 \%$ & None \\
\hline Suzuki et al. 2000 & 111 & $61 \%$ & $\begin{array}{l}\text { Positive association: } \mathrm{ER} \alpha, \mathrm{PR} \\
\text { Inverse association: Histological grade, Ki67 }\end{array}$ \\
\hline
\end{tabular}

Table 3 Summary of immunohistochemical analysis of STS in breast carcinoma tissues

\begin{tabular}{lccl}
\hline Study & $\begin{array}{c}\text { No. of cases } \\
\text { examined }\end{array}$ & $\begin{array}{c}\text { \% of STS } \\
\text { positive cases }\end{array}$ & $\begin{array}{c}\text { Association between STS immunoreactivity } \\
\text { and clinicopathological parameters }\end{array}$ \\
\hline Saeki et al. 1999 & 25 & $88 \%$ & None \\
Suzuki et al. 2003 & 113 & $74 \%$ & $\begin{array}{l}\text { Positive association: Tumor size, increased } \\
\text { risk of recurrence } \\
\text { None }\end{array}$ \\
Yamamoto et al. 2003 & 83 & $59 \%$ & None
\end{tabular}

expression in breast carcinomas. Retinoic acid induces the expression of 17ßHSD1 mRNA in T47D breast cancer cells (Reed et al. 1994), and a significant correlation was detected between retinoic acid receptor (RAR)- $\alpha$ and 17ßHSD1 immunoreactivity (Suzuki et al. 2001b). In addition, Simard and Gingras (2001) reported that IL-4 and IL-6 increased oxidative 17ßHSD activity in ZR-75-1 cells, but IL-4 stimulated the reductive $17 \beta \mathrm{HSD}$ activity in T-47D cells. The effects of cytokines on $17 \beta$ HSD activity appear to vary in different cell lines, and cytokines are considered to play important roles in the modulation of $17 \beta \mathrm{HSD}$ activity in breast carcinoma tissues (Purohit et al. 2002). An induction of $17 \beta$ HSD1 expression by progestins has also been reported in several breast cancer cells (Poutanen et al. 1992b, Pasqualini 2003), which may partly explain the proliferative effects of progestins on breast cancer cells through the accumulation of estrogenic actions; however, further examinations are required to establish this hypothesis (Pasqualini 2003).

\section{STS}

STS is a single enzyme that hydrolyzes several sulfated steroids such as estrone sulfate, dehydroepiandrosterone (DHEA) sulfate, and cholesterol sulfate (Reed et al. 2005). A major circulating form of plasma estrogens in postmenopausal women is estrone sulfate, a biologically inactive form of estrogen. Estrone sulfate has a relatively long half-life in the peripheral blood, and the levels of estrone sulfate are 5 to 10 times higher than those of unconjugated estrogens such as estrone, estradiol and estriol during the menstrual cycle and in postmenopausal women (Pasqualini 2004). STS catalyzes estrone sulfate to estrone in breast carcinoma (Fig. 2), which contributes to local estrogen production. The enzymatic activity of STS is detected in the great majority of breast tumors, and is considerably higher than aromatase activity in breast tumors (Santner et al. 1984, Evans et al. 1994). Evans et al. (1994) reported no significant association between STS activity and time to recurrence or overall survival time in breast cancer patients examined in their study. STS activity was correlated with the level of STS mRNA expression in breast cancer cells (Pasqualini et al. 1994). The STS mRNA expression was higher in breast carcinoma tissues than that in normal tissues (Utsumi et al. 1999), which is also consistent with the findings of STS activity in breast cancers described above. Furthermore, STS mRNA expression has been reported to be significantly associated with poor clinical outcome of patients (Utsumi et al. 1999, Miyoshi et al. 2003). Reed et al. (2005) proposed that the sulfatase pathway might be more important than the aromatase route for intratumoral estrogen synthesis in breast cancers, because aromatase mRNA expression was reported to have no significant prognostic value.

STS mRNA expression was detected in breast carcinoma cells, but not in intratumoral stromal cells, by LCM/real-time PCR (Suzuki et al. 2003), which was consistent with immunohistochemical findings. STS immunoreactivity was detected in carcinoma cells in $59-88 \%$ of breast carcinoma cases (Saeki et al. 1999, Suzuki et al. 2003, Yamamoto et al. 2003) (Fig. 4D) (Table 3), and STS immunoreactivity was significantly associated with its mRNA level (Suzuki et al. 2003). 
STS immunoreactivity was correlated with tumor size, and was significantly associated with an increased risk of recurrence (Suzuki et al. 2003). No significant correlation has been reported between STS and ER status in human breast cancer tissues in these studies. STS also allows the conversion of DHEA sulfate to DHEA; therefore, this conversion may be partly associated with a local accumulation of DHEA, a precursor substrate for both active estrogens and androgens, from circulating DHEA sulfate in breast cancer tissue.

Little is known about the regulatory mechanism of STS in breast cancers. IL-6 and TNF $\alpha$ stimulated STS activity and acted synergistically to increase enzyme activity, possibly via a post-transcriptional modification of the enzyme (Newman et al. 2000). In addition, progestins and anti-estrogens have been reported to inhibit the expression and/or activity of STS in breast cancer cells (Pasqualini \& Chetrite 2005).

\section{3ß-Hydroxysteroid dehydrogenase}

$3 \beta$-Hydroxysteroid dehydrogenase (3ßHSD) is a membrane-bound enzyme responsible for the interconversion of $3 \beta$-hydroxy- and 3-keto- $5 \alpha$-androstane steroids. Two isoforms of $3 \beta \mathrm{HSD}$, i.e. $3 \beta \mathrm{HSD} 1$ and $3 \beta \mathrm{HSD} 2$, have been characterized in humans. 33HSD2 is mainly expressed in the adrenal glands and gonads (Rheaume et al. 1991), and is a crucial step in the biosynthesis of various steroid hormones such as progesterone, estrogens, androgens, glucocorticoids and mineralocorticoids. On the other hand, 33HSD1 is predominantly expressed in the placenta and various non-classical steroidogenic tissues such as skin and breast (Rheaume et al. 1991). In the non-classical steroidogenic tissues, $3 \beta \mathrm{HSD}$ is considered mainly to catalyze DHEA into androstenedione, and to increase the local tissue levels of androstenedione, a precursor substrate for both bioactive estrogens and androgens (Labrie et al. 2003) (Fig. 2). Therefore, 3ßHSD may also play a part in the initial step of the intracrine transformation in breast carcinoma. Limited information is available on the expression of $3 \beta \mathrm{HSD}$ in breast carcinoma tissues. However, 33HSD activity has been detected in breast carcinomas (Gunasegaram et al. 1998). Sasano et al. (1994) reported that 33HSD immunoreactivity, which recognized both $3 \beta \mathrm{HSD}$ isoforms, was localized in breast carcinoma cells in $12(33 \%)$ of 33 breast cancer tissues, but was not significantly associated with the ER or PR status.

$3 \beta H S D$ activity has been detected widely among peripheral tissues, although $3 \beta \mathrm{HSD}$ protein itself was not necessarily detected (Milewich et al. 1991).
17ßHSD2 also possesses 3ßHSD activity, and can catalyze DHEA to androstenedione (Suzuki et al. 2000b). 17ßHSD2 expression appears to be negligible in breast cancer tissues, but dual activity of certain steroid-specific oxidoreductases may be associated with 33HSD activity in breast cancers.

Previous studies demonstrated enhancement of 33HSD2 transcription by SF1 (Leers-Sucheta et al. 1997) or LRH-1 (Sirianni et al. 2002). Expression of $3 \beta \mathrm{HSD} 1$ was also regulated by cAMP or protein kinase-C (Tremblay \& Beaudoin 1993). However, in contrast to $3 \beta \mathrm{HSD} 2$, regulation of $3 \beta \mathrm{HSD} 1$ by SF1 has not been clarified. The regulatory mechanism of 33HSD1 in human breast cancers is unclear, but Gingras et al. $(1999,2000)$ reported induction of $3 \beta$ HSD1 gene transcription by IL-4 and IL-13 in breast cancer cells.

\section{Estrogen-metabolizing enzymes: estrogen sulfotransferase}

The potency of steroid hormones is generally reduced in the metabolic process towards inactive products in the same tissue sites as the synthesis and/or action, which contributes to the modulation of overall biological actions of steroid hormones. Therefore, it is very important to examine the expression of estrogenmetabolizing enzymes as well as that of estrogenproducing enzymes to assess the local estrogen levels in breast cancers.

Estrogen sulfotransferase (EST; SULT1E1) is a member of the superfamily of steroid-sulfotransferases; it sulfonates estrogens to biologically inactive estrogen sulfates (Aksoy et al. 1994, Falany et al. 1995) (Fig. 2). EST has the lowest $K_{\mathrm{m}}$ values for estrogens of the 10 known human sulfotransferase (SULT) isoforms (Adjei et al. 2003), and is also considered to be involved in the regulation of in situ estrogen levels in human breast carcinoma. The concentration of estrone sulfate was significantly (7-11 times) higher in breast cancer tissues than in plasma (Pasqualini et al. 1996), and the enzymatic activity of EST was detected in some breast cancer cell lines (Falany \& Falany 1996, Chetrite et al. 1998), breast carcinoma tissues, and normal breast tissues (Adams et al. 1979, Tseng et al. 1983). EST enzymatic activity was associated with ER status in breast cancer tissues (Adams et al. 1979, Tseng et al. 1983). MCF7 breast cancer cells transfected with EST possess EST activity at levels similar to normal human mammary epithelial cells, and are associated with much lower estrogen-stimulated DNA synthesis or cell proliferation than control MCF7 cells that do not possess EST, suggesting that the 
loss of EST expression in the transformation of normal breast tissues to breast cancer may be an important factor in increasing the growth responsiveness of preneoplastic or tumor cells to estrogen stimulation (Qian et al. 1998, Falany et al. 2002).

EST mRNA expression was detected in breast cancer tissues (Suzuki et al. 2003, Yoshimura et al. 2004), and was significantly associated with EST immunoreactivity (Suzuki et al. 2003). EST immunoreactivity was detected in carcinoma cells in $44 \%$ of human breast carcinomas, and was also present in the epithelial cells of normal glands (Suzuki et al. 2003). EST immunoreactivity was inversely correlated with tumor size or lymph node status, and was significantly associated with a decreased risk of recurrence or improved prognosis (Suzuki et al. 2003). However, EST immunoreactivity was not significantly correlated with ER status in breast cancer tissues (Suzuki et al. 2003), which was inconsistent with the results of the EST enzymatic activity described above (Adams et al. 1979, Tseng et al. 1983). It may be partly due to the fact that other members of the steroid-sulfotransferase superfamily, such as thermostable phenol sulfotransferase (P-PST; SULT1A1) and the monoamine sulfating form of phenol sulfotransferase (M-PST; SULT1A3) can also sulfonate estrogens to estrogen sulfates. Spink et al. (2000) reported expression of P-PST and M-PST in several breast cancer cell lines, but the biological significance of P-PST and M-PST in breast cancer tissues remains largely unclear at this juncture.

\section{Other estrogen-metabolizing enzymes: CYP1A1, CYP1B1, and CYP3A4}

The CYP superfamily is classified into families and subfamilies based on amino acid similarity, and 14 families have been reported in mammals. CYPs are involved in synthesis of steroid and bile acids and hydroxylation of fatty acids, or elimination of xenobiotics and steroids from the body (Bistolas et al. 2005). Among the CYP superfamily, CYP1A1, CYP1B1, and CYP3A4 oxidatively metabolize estradiol, and these findings suggest the possible association with regulation of local estrogen levels in breast cancer tissues.

CYP1A1 catalyzes C-2, C-6 $\alpha$ and C- $15 \alpha$ hydroxylation of estradiol. CYP1A1 mRNA expression was detected in $25-46 \%$ of normal breast tissues (Huang et al. 1996, Iscan et al. 2001) and 5-53\% of breast carcinoma tissues (Huang et al. 1996, Hellmold et al. 1998, Iscan et al. 2001). Using quantitative RT-PCR analysis, Modugno et al. (2003) reported that CYP1A1
mRNA expression was elevated in non-tumor tissue among pairs in which the tumor expressed ER. In immunoblotting analysis, CYP1A1 protein was detected in $36 \%$ of breast cancer tissues (Hellmold et al. 1998), and the CYP1A1 protein level was significantly lower in breast cancer tissue as compared with morphologically normal adjacent tissues (ElRayes et al. 2003).

On the other hand, CYP1B1 shows activity towards the C4-hydroxylation of estradiol. Expression of CYP1B1 mRNA was detected in $100 \%$ of breast carcinoma tissues (Hellmold et al. 1998, Iscan et al. 2001), and the level of expression was significantly higher in non-tumor tissues than in tumor tissues (Modugno et al. 2003). CYP1B1 immunoreactivity was detected in carcinoma cells in $77-82 \%$ of breast cancers by immunohistochemistry (McFadyen et al. 1999, Oyama et al. 2005). McFadyen et al. (1999) found no significant association between CYP1B1 immunoreactivity and clinicopathological factors, including tumor grade and ER status in the breast carcinomas, while Oyama et al. (2005) reported an inverse correlation between CYP1B1 immunoreactivity and clinical stage in breast cancers.

CYP1A1 and CYP1B1 metabolize not only estrogens but also some environmental carcinogens. It is well known that CYP1A1 and CYP1B1 are under the regulation of aryl hydrocarbon receptor (AhR), and these two enzymes are induced by AhR agonists such as 2,3,7,8-tetrachlorodibenzo-p-dioxin (TCDD) (Angus et al. 1999, Kristensen \& Borresen-Dale 2000). However, CYP1B1 expression is constitutively detected in breast carcinoma tissues as described above, and CYP1B1 is considered as a major form of the CYP1 family in breast cancer. Regulation of CYP1A1 and CYP1B1 expression by estrogen has also been reported in breast cancer cells (Angus et al. 1999). Recently, Tsuchiya et al. (2004) demonstrated the induction of CYP1B1 mRNA expression by estradiol in ER-positive MCF7 cells, but not ER-negative MDA-MB-435 cells, and suggested that the induction of CYP1B1 mRNA was caused by the ER-mediated pathway rather than the AhR-mediated pathway.

CYP3A4 plays a pivotal role in activating and detoxifying various xenobiotics and endobiotics. CYP3A4 also catalyzes the $\mathrm{C} 2, \mathrm{C} 4, \mathrm{C} 6 \alpha \beta, \mathrm{C} 12$, $\mathrm{C} 15 \alpha$, and $\mathrm{C} 16 \alpha \beta$-hydroxylation of estrogen. Several groups reported the expression of CYP3A in breast carcinoma tissues, but these results appear to be inconsistent. Hellmold et al. (1998) detected CYP3A4 mRNA expression in $73 \%$ of breast carcinoma tissues, and Modugno et al. (2003) reported that the expression level of CYP3A4 mRNA was significantly higher in 
non-tumor tissues than in tumor tissues. However, Iscan et al. (2001) reported no mRNA expression of CYP3A4 in breast tumor tissues or normal breast tissues. In immunoblotting analysis, El-Rayes et al. (2003) reported that CYP3A4 protein levels were significantly lower in breast carcinoma tissues than in morphologically normal adjacent tissues, while Hellmold et al. (1998) did not detect CYP3A protein in 15 breast carcinoma tissues. In immunohistochemical analysis, CYP3A4 immunoreactivity was detected in $84-100 \%$ of breast carcinoma tissues, and normal mammary epithelium was focally positive (Galant et al. 2001, Kapucuoglu et al. 2003). Galant et al. (2001) reported an inverse association between CYP3A immunoreactivity and the proliferation index. On the other hand, Oyama et al. (2005) did not detect CYP3A immunoreactivity in 34 cases of Japanese patients with breast cancers, and suggested that, based on their findings, CYP3A expression in breast cancer was possibly dependent on the ethnicity of the patient.

CYP3A4 gene expression is induced by nuclear receptors such as steroid and xenobiotic receptor/ pregnane X receptor (SXR/PXR; NR1I2) and constitutive androstane receptor (CAR; NR1I3), and is repressed by proinflammatory cytokines in hepatocytes (Raunio et al. 2005). Masuyama et al. (2003, 2005) reported induction of CYP3A4 by SXR/PXR in endometrial cancer, but the regulation mechanism of CYP3A4 in breast cancer still remains unclear.

4-Hydroxy-estradiol, which is metabolized by CYP1B1 or CYP3A4 from estradiol, is further converted to the 3,4 estradiol quinone. This compound is recognized as a genotoxic mutagenic carcinogen, and possibly induces breast cancer (Liehr 2000). Therefore, metabolism of estradiol by CYP1B1 and CYP3A4 may not necessarily be associated with reducing the progression of breast tumors. Further examinations are required to clarify the biological significance of CYP1B1 and CYP3A4 in human breast cancer tissues.

\section{Intratumoral production of androgens in breast cancer}

Various previous studies demonstrated that androgens predominantly exerted anti-proliferative effects on the mitogenic effects of estrogens in breast cancer cell lines, although some divergent findings have been reported according to the specific cell line used, the androgen used and its dose, and estrogen status (Ortmann et al. 2002, Somboonporn \& Davis 2004). This inhibitory effect is mediated by AR, and is partly associated with increased levels of p21 and/or p27 (Lapointe \& Labrie 2001, Greeve et al. 2004). Previously, Isola (1993) reported that approximately $80 \%$ of breast carcinomas expressed AR, suggesting the presence of androgenic actions in human breast carcinoma tissues. Plasma concentrations of potent androgens such as $5 \alpha-$ dihydrotestosterone (DHT) are very low in normal women and in breast cancer patients (Labrie et al. 2003). However, DHT concentrations were significantly (threefold) higher in breast cancer tissues than in plasma (Recchione et al. 1995), suggesting the possible local production of DHT and an important biological role of DHT in breast carcinoma tissues. Two steroidogenic enzymes, namely $17 \beta$ HSD5 and $5 \alpha$-reductase, are considered to be the main enzymes involved in local androgen production in human breast cancer tissues (Fig. 2).

\section{7ßHSD5}

It is well known that testosterone is mainly secreted from the Leydig cells of the testis, and it is biosynthesized from androstenedione by 17ßHSD3 (Geissler et al. 1994). However, testicular Leydig cells provide approximately $50 \%$ of the total amount in men, and the rest of the amount is converted from circulating androstendione in peripheral tissues (Labrie et al. 2003). 17ßHSD3 is predominantly expressed in the testis, while the same enzymatic reaction in peripheral tissues is catalyzed by different enzymes, namely 17ßHSD5 (Dufort et al. 1999). 17ßHSD5 is identical to $3 \alpha \mathrm{HSD} 2$. $17 \beta \mathrm{HSD} 5$ is a member of the aldo-keto reductase (AKR) superfamily, and is formally termed AKR1C3, while 17ßHSD1 to 3 are members of the short-chain dehydrogenase/reductase (SDR) superfamily (Penning et al. 2001).

mRNA expression of $17 \beta$ HSD5 was detected in $65-83 \%$ of breast carcinoma tissues (Ji et al. 2004, Vihko et al. 2005). In particular Vihko et al. (2005) reported that $17 \beta$ HSD5 mRNA expression was significantly higher in breast tumor specimens than in normal tissues. They also demonstrated that a group of patients with overexpression of 17ßHSD5 mRNA had a worse prognosis than other patients (Vihko et al. 2005). 17ßHSD5 immunoreactivity was detected in normal mammary gland (Pelletier et al. 1999) and breast carcinoma cells in $53 \%$ of cases (Suzuki et al. 2001a) (Fig. 4E). Immunoreactivity of 17ßHSD5 was significantly associated with that of $5 \alpha$-reductase type 1 and type 2 (Suzuki et al. 2001a), but was not significantly associated with other clinicopathological factors such as patient age, menopausal status, clinical stage, tumor size, lymph node status, histological 
grade, ER, PR, AR, Ki67, and HER2, examined in 60 breast carcinoma tissues ( $\mathrm{T}$ Suzuki, Y Miki, Y Nakamura, T Moriya, K Ito, N Ohuchi, H Sasano, unpublished data).

17ßHSD5 also possesses $3 \alpha \mathrm{HSD}$ and $20 \alpha \mathrm{HSD}$ activities (Luu-The et al. 2001). The $3 \alpha$ HSD and $20 \alpha$ HSD activities are involved in the inactivation of progesterone (Wiebe et al. 2000, Luu-The et al. 2001, Suzuki et al. 2002). The biological significance of $17 \beta$ HSD5 in these activities, however, still remains unclear in breast cancer tissues.

\section{$5 \alpha$-Reductases}

$5 \alpha$-Reductase catalyzes the conversion of testosterone to a more potent androgen DHT (Russell \& Wilson 1994) (Fig. 2), and is considered as an important regulator of local actions of androgens. Two isoforms of $5 \alpha$-reductase have been cloned and characterized in mammals. $5 \alpha$-Reductase type 1 is located on the distal short arm of chromosome 5, and is mainly expressed in the liver and skin (Russell \& Wilson 1994, Jin \& Penning 2001). On the other hand, type $25 \alpha$-reductase is located in band p23 of chromosome 2, and is expressed in the liver, prostate, seminal vesicle, and epididymis (Russell \& Wilson 1994, Jin \& Penning 2001).

Activity of $5 \alpha$-reductase was previously detected in human breast carcinoma cell lines (MacIndoe \& Woods 1981), and $5 \alpha$-reductase activity was elevated 4-8 times in breast cancer tissues compared with non-tumorous breast tissues (Wiebe et al. 2000). mRNA expression of $5 \alpha$-reductase type 1 was detected in all the breast carcinoma tissues examined (Suzuki et al. 2001a, Lewis et al. 2004, Ji et al. 2004), while that of $5 \alpha$-reducatase type 2 was detected in $38-100 \%$ of the tumors ((Suzuki et al. 2001a, Lewis et al. 2004). Lewis et al. (2004) also demonstrated that mRNA expression levels of $5 \alpha$-reductase type 1 and type 2 were significantly higher in the tumors than in corresponding normal tissues. Immunoreactivity for $5 \alpha-$ reductase type 1 was detected in $58 \%$ of breast carcinomas (Fig. 4F), while that of $5 \alpha$-reductase type 2 was detected in only $15 \%$ of breast carcinomas (Suzuki et al. 2001a), suggesting that $5 \alpha$-reductase type 1 may mainly determine $5 \alpha$-reductase activity in breast carcinoma tissues. $5 \alpha$-Reductase type 1 immunoreactivity was significantly correlated with $\mathrm{AR}$, and inversely associated with histological grade or tumor size in breast carcinoma tissues (Suzuki et al. 2001a). Therefore, breast carcinomas positive for $5 \alpha$-reductase type 1 may partly maintain some androgen regulatory mechanisms.

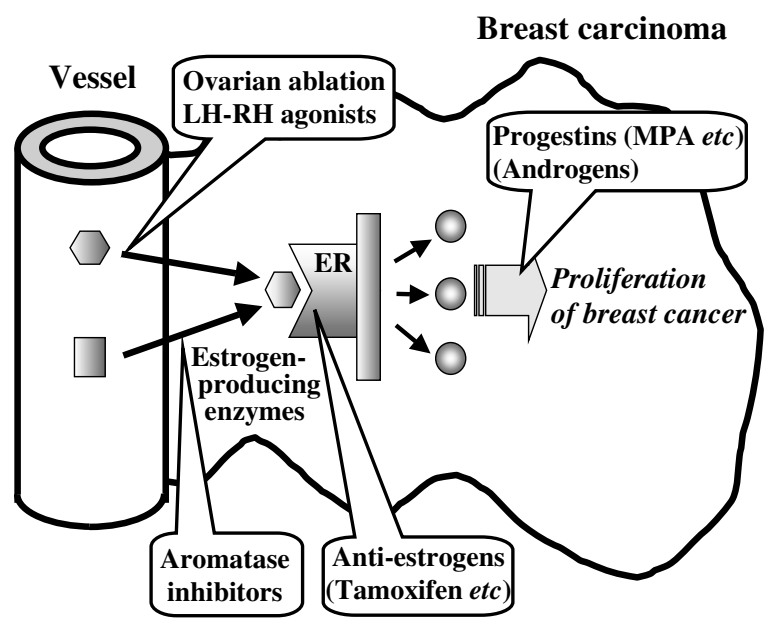

Figure 5 Scheme representing local estrogen actions and endocrine therapies in human breast carcinoma. Bioactive estrogen promotes proliferation of breast carcinoma through several pathways, and these pathways are targets of the endocrine therapies. $\square$, inactive hormone; $\square$, bioactive hormone; $\square$, receptor; $\square$, promoter region of the target gene; $O$, estrogen-responsive gene.

MPA, medroxyprogestrone acetate.

$5 \alpha$-Reductase metabolizes progesterone to $5 \alpha$ dihydroprogesterone ( $5 \alpha$-DHP) (Russell \& Wilson 1994), suggesting that this enzyme is also involved in the local regulation of progesterone actions. Wiebe et al. (2000) reported that in breast cancer progesterone was metabolized to $5 \alpha$-DHP and $3 \alpha$-hydroxyprogesterone $(3 \alpha-\mathrm{HP})$ by $5 \alpha$-reductase and $3 \alpha-\mathrm{HSD}$ respectively, and the ratio of $5 \alpha-\mathrm{DHP}: 3 \alpha-\mathrm{HP}$ was nearly 30 -fold higher in tumorous than in nontumorous breast tissues. They also reported that $5 \alpha$-DHP stimulated, whereas $3 \alpha$-HP inhibited, proliferation and detachment of breast cell lines in vitro (Wiebe et al. 2000). These findings suggest that some progesterone metabolites exhibit different bioactive properties from progesterone, and $5 \alpha$-reductase may be partly associated with the proliferation effect of progesterone in breast cancer cells (Wiebe et al. 2005).

\section{Regulation of in situ estrogen production in breast carcinomas as an endocrine therapy}

It is well known that estrogen deprivation therapy is an effective treatment for breast cancer, and various types of endocrine therapy are currently available in breast cancer patients (Fig. 5). Ovarian suppression is important for the treatment of premenopausal breast 
cancers, and ovarian ablation or treatment with luteinizing hormone releasing hormone (LH-RH) agonists is frequently considered in premenopausal patients (Robertson \& Blamey 2003). On the other hand, since biological effects of estrogens are mediated through ER, anti-estrogens such as tamoxifen have been used as endocrine therapy in hormone-receptorpositive breast carcinomas of both pre- and postmenopausal women (Eneman et al. 2004).

The importance of in situ estrogen production has been demonstrated in breast carcinomas, as described in the above sections of this review, and the inhibition of this pathway is considered clinically useful for reducing the progression of breast tumors especially in postmenopausal women. The third-generation aromatase inhibitors, such as anastrozole, letrozole and exemestane, are currently available (Brueggemeier et al. 2005). Results of large multicenter trials such as the ATAC trial, the NCIC MA-17 trial, and the Intergroup Exemestane Study, all demonstrated that aromatase inhibitors are significantly associated with the improved disease-free survival and good tolerability in breast cancer patients (Baum et al. 2002, 2003, Goss et al. 2003, Baum 2004, Coombes et al. 2004, Howell et al. 2005), and anastrolozole demonstrated superior efficacy to tamoxifen in the ATAC trial. ER status in the breast carcinoma is the most influential parameter to determine the administration of aromatase inhibitors at this juncture. However, it is true that additional factors are required to improve the clinical effects of aromatase inhibitor in breast cancer patients. Previous studies reported an association between aromatase activity in breast carcinoma tissues and the response to treatment with aromatase inhibitors (Bezwoda et al. 1987, Miller \& O’Neill 1987), but it may not necessarily be a useful surrogate marker to determine clinically the treatment of aromatase inhibitor, because of the lack of robust assays for tumor aromatase (Miller et al. 2003). In this regard, immunohistochemistry for aromatase is expected to be the attractive routine method, considering the great success in detecting ER, PR and HER2 in breast cancer tissues. However, further examinations are certainly required to establish a standardized approach, including the determination of aromatase antibody, the immunohistochemical procedure and the evaluation system. Cyclooxygenase- 2 (COX2) is partly associated with the synthesis of $\mathrm{PGE}_{2}$, a potent stimulator of aromatase, in breast cancers (Diaz-Cruz et al. 2005), and therefore, clinical trials are currently underway to examine synergistic effects between COX2 inhibitor and aromatase inhibitor in postmenopausal women (Arun \& Goss 2004).
Table 4 Association among immunoreactivity of enzymes related to intratumoral estrogen production and ERs in breast carcinoma tissues

\begin{tabular}{llllll}
\hline Immunoreactivity & $\mathbf{1 7} \alpha \mathrm{HSD} \mathbf{1}$ & $\mathbf{S T S}$ & $\mathrm{EST}$ & $\mathrm{ER} \boldsymbol{\alpha}$ & ER $\boldsymbol{\alpha}$ \\
\hline Aromatase & NS & NS & NS & NS & NA \\
$17 \alpha \mathrm{HSD} 1$ & & NS & NS & $<0.05$ & $<0.05^{*}$ \\
STS & & & NS & NS & NS \\
EST & & & & NS & NS \\
ER $\alpha$ & & & & & $<0.01^{*}$ \\
ER $\alpha$ & & & & & \\
\hline
\end{tabular}

Data were taken from a series of our examinations (Sasano et al. 1994, Sasano et al. 1996, Suzuki et al. 2000a, Suzuki et al. 2003), and adapted.

*; unpublished data, and NA; data not available.

$17 \alpha \mathrm{HSD} 2$ immunoreactivity was not detected in all the cases examined (Suzuki et al. 2000a).

Aromatase is a key enzyme of intratumoral production of estrogen in breast cancers. However, Yamaguchi et al. (2005) reported that estrogen signals in breast cancer cells were not always correlated with aromatase expression in stromal cells of carcinoma tissues, suggesting that even complete suppression of aromatase does not fully block the estrogenic actions in breast cancer tissues. When we examined an association among the immunoreactivity of enzymes related to intratumoral production and ERs in breast carcinoma tissues, no significant association was detected (Table 4). Therefore, enzymes responsible for the intratumoral production of estrogen may not always be the same among breast cancer patients, and other estrogen-producing enzymes, with the exception of aromatase, including STS and 17ßHSD1 may also have important therapeutic potential as endocrine therapy for total blockade of local estrogen in breast cancer tissues. STS inhibitors were reported to be effective in suppressing the proliferation of estrogendependent MCF7 cells when estrone sulfate was the source of estrogen, and STS inhibitors are currently being developed by several groups (Nussbaumer \& Billich 2004, Reed et al. 2005). The design of 17ßHSD1 inhibitors has also been attempted (Qiu et al. 2002, Poirier 2003).

Sakamoto et al. (2002) showed that proliferation of ER-positive breast cancer cells increased in medium to which average levels of postmenopausal plasma steroids had been added, but the growth was not stimulated in the transformed cells overexpressing $17 \beta$ HSD2 or EST in the same medium. These findings suggest that induction of $17 \beta \mathrm{HSD} 2$ or EST can also effectively contribute to the decrement of intratumoral estrogen production in breast cancer. In addition, Pasqualini (2003) reported that the progestin, 
medrogestone, stimulates EST in breast cancer cells through decreasing estrogen-dependent cell proliferation. Therefore, induction of estrogen-metabolizing enzymes is also considered to result in a decrement of estrogenic actions in breast carcinoma tissues, which may eventually contribute to an improvement in the prognosis of breast cancer patients.

Activation of ER by growth factors, such as epidermal growth factor (EGF), insulin-like growth factor-I (IGF-I), and transforming growth factor- $\alpha$ (TGFo) (Surmacz \& Bartucci 2004, Osborne et al. 2005) has also been demonstrated. HER2-overexpressing breast cancers frequently become resistant to tamoxifen (Osborne et al. 2003), and aromatase inhibitors were more effective in these patients (Ellis et al. 2001). Cross-talk between $\mathrm{ER} \alpha$ and growth factor receptor signals is postulated to be important especially in the mechanism of tamoxifen resistance in breast cancer, and double blockade using both ER-targeted therapies and therapies targeting the growth factor receptor cascade is currently being tested in clinical trials (Osborne et al. 2005).

In contrast to estrogens, androgens are generally known to inhibit the proliferation of breast carcinoma cells. A strong correlation between AR and ER was detected in breast cancer tissues (Isola 1993, Suzuki et al. 2001a), and frequently estrogen-dependent breast cancers are also dependent on androgenic actions. When androgens were combined with anti-estrogens in breast cancer patients, a higher response rate and a longer time to disease progression have been reported compared with the administration of an anti-estrogen alone, and the additive inhibitory effects of androgens and anti-estrogens on breast carcinoma are exerted, in part, by different mechanisms (Labrie et al. 2003). On the other hand, Sonne-Hansen and Lykkesfeldt (2005) recently reported that proliferation of MCF7 cells was significantly stimulated by testosterone, and the testosterone-mediated growth effect was completely inhibited by aromatase inhibitors. They also reported that androstendione did not significantly stimulate MCF7 cell proliferation, and suggested that the preferred substrate for aromatase in MCF7 cells is not androstendione but testosterone (Sonne-Hansen \& Lykkesfeldt 2005). 17ßHSD5 locally produces testosterone from androstenedione, and also converts progesterone to its inactive metabolite $20 \alpha$-hydroprogesterone. Therefore, $17 \beta$ HSD 5 may partly be associated with a pro-estrogenic state (Penning et al. 2001) in addition to the in situ androgen production in breast carcinoma, and may also become a therapeutic target to decrease the intratumoral estrogen production in breast cancer.
The clinical significance of aromatase inhibitors demonstrated that inhibition of estrogen-producing enzymes is effective in reducing the progression of breast carcinomas, and the endocrine therapy for breast cancer could be improved if inhibitors for other related enzymes become clinically available. Therefore, it will become very important accurately to evaluate the expression of various sex-steroid producing enzymes in resected surgical pathology specimens, to determine the treatment by appropriate inhibitors for the enzymes in individual breast cancer patients.

\section{Acknowledgements}

The authors declare that there is no conflict of interest that would prejudice the impartiality of this scientific work.

\section{References}

Adams JB, Pewnim T, Chandra DP, Archibald L \& Foo MS 1979 A correlation between estrogen sulfotransferase levels and estrogen receptor status in human primary breast carcinoma. Cancer Research 39 5124-5126.

Adjei AA, Thomae BA, Prondzinski JL, Eckloff BW, Wieben ED \& Weinshilboum RM 2003 Human estrogen sulfotransferase (SULT1E1) pharmacogenomics: gene resequencing and functional genomics. British Journal of Pharmacology 139 1373-1382.

Aksoy IA, Wood TC \& Weinshilboum R 1994 Human liver estrogen sulfotransferase: identification by cDNA cloning and expression. Biochemical and Biophysical Research Communications 200 1621-1629.

Angus WG, Larsen MC \& Jefcoate CR 1999 Expression of CYP1A1 and CYP1B1 depends on cell-specific factors in human breast cancer cell lines: role of estrogen receptor status. Carcinogenesis 20 947-955.

Ariga N, Moriya T, Suzuki T, Kimura M, Ohuchi N, Satomi S \& Sasano H 2000 17Beta-hydroxysteroid dehydrogenase type 1 and type 2 in ductal carcinoma in situ and intraductal proliferative lesions of the human breast. Anticancer Research 20 1101-1108.

Arun B \& Goss P 2004 The role of COX-2 inhibition in breast cancer treatment and prevention. Seminars in Oncology 31 22-29.

Baum M 2004 Current status of aromatase inhibitors in the management of breast cancer and critique of the NCIC MA-17 trial. Cancer Control 11 217-221.

Baum M, Budzar AU, Cuzick J, Forbes J, Houghton JH, Klijn JG \& Sahmoud T and the ATAC Trialists' Group 2002 Anastrozole alone or in combination with tamoxifen versus tamoxifen alone for adjuvant treatment of postmenopausal women with early breast cancer: first results of the ATAC randomised trial. Lancet 359 2131-2139. 
Baum M, Buzdar A, Cuzick J, Forbes J, Houghton J, Howell A \& Sahmoud T and the ATAC (Arimidex, Tamoxifen Alone or in Combination) Trialists' Group 2003 Anastrozole alone or in combination with tamoxifen versus tamoxifen alone for adjuvant treatment of postmenopausal women with early-stage breast cancer: results of the ATAC (Arimidex, Tamoxifen Alone or in Combination) trial efficacy and safety update analyses. Cancer 98 1802-1810.

Bezwoda WR, Mansoor N \& Dansey R 1987 Correlation of breast tumour aromatase activity and response to aromatase inhibition with aminoglutethimide. Oncology 44 345-349.

Bistolas N, Wollenberger U, Jung C \& Scheller FW 2005 Cytochrome P450 biosensors - a review. Biosensors and Bioelectronics 20 2408-2423.

Bolufer P, Ricart E, Lluch A, Vazquez C, Rodriguez A, Ruiz A, Llopis F, Garcia-Conde J \& Romero R 1992 Aromatase activity and estradiol in human breast cancer: its relationship to estradiol and epidermal growth factor receptors and to tumor-node-metastasis staging. Journal of Clinical Oncology 10 438-446.

Brodie AM, Lu Q, Long BJ, Fulton A, Chen T, Macpherson N, DeJong PC, Blankenstein MA, Nortier JW, Slee PH, van de Ven J, van Gorp JM, Elbers JR, Schipper ME, Blijham GH \& Thijssen JH 2001 Aromatase and COX-2 expression in human breast cancers. Journal of Steroid Biochemistry and Molecular Biology 79 41-47.

Brueggemeier RW, Hackett JC \& Diaz-Cruz ES 2005 Aromatase inhibitors in the treatment of breast cancer. Endocrine Reviews 26 331-345.

Bulun SE, Price TM, Aitken J, Mahendroo MS \& Simpson ER 1993 A link between breast cancer and local estrogen biosynthesis suggested by quantification of breast adipose tissue aromatase cytochrome P450 transcripts using competitive polymerase chain reaction after reverse transcription. Journal of Clinical Endocrinology and Metabolism 77 1622-1628.

Chetrite G, Le Nestour E \& Pasqualini JR 1998 Human estrogen sulfotransferase (hEST1) activities and its mRNA in various breast cancer cell lines. Effect of the progestin, promegestone (R-5020). Journal of Steroid Biochemistry and Molecular Biology 66 295-302.

Chetrite GS, Cortes-Prieto J, Philippe JC, Wright F \& Pasqualini JR 2000 Comparison of estrogen concentrations, estrone sulfatase and aromatase activities in normal, and in cancerous, human breast tissues. Journal of Steroid Biochemistry and Molecular Biology 72 23-27.

Clyne CD, Speed CJ, Zhou J \& Simpson ER 2002 Liver receptor homologue-1 (LRH-1) regulates expression of aromatase in preadipocytes. Journal of Biological Chemistry 277 20591-20597.

Coombes RC, Hall E, Gibson LJ, Paridaens R, Jassem J, Delozier T, Jones SE, Alvarez I, Bertelli G, Ortmann O, Coates AS, Bajetta E, Dodwell D, Coleman RE,
Fallowfield LJ, Mickiewicz E, Andersen J, Lonning PE, Cocconi G, Stewart A, Stuart N, Snowdon CF, Carpentieri M, Massimini G \& Bliss JM and the Intergroup Exemestane Study 2004 A randomized trial of exemestane after two to three years of tamoxifen therapy in postmenopausal women with primary breast cancer. New England Journal of Medicine 350 1081-1092.

Diaz-Cruz ES, Shapiro CL \& Brueggemeier RW 2005 Cyclooxygenase inhibitors suppress aromatase expression and activity in breast cancer cells. Journal of Clinical Endocrinology and Metabolism 90 2563-2570.

Dufort I, Rheault P, Huang XF, Soucy P \& Luu-The V 1999 Characteristics of a highly labile human type 5 17 beta-hydroxysteroid dehydrogenase. Endocrinology $140568-574$.

Ellis MJ, Coop A, Singh B, Mauriac L, Llombert-Cussac A, Janicke F, Miller WR, Evans DB, Dugan M, Brady C, Quebe-Fehling E \& Borgs M 2001 Letrozole is more effective neoadjuvant endocrine therapy than tamoxifen for ErbB-1- and/or ErbB-2-positive, estrogen receptorpositive primary breast cancer: evidence from a phase III randomized trial. Journal of Clinical Oncology 19 3808-3816.

El-Rayes BF, Ali S, Heilbrun LK, Lababidi S, Bouwman D, Visscher D \& Philip PA 2003 Cytochrome p450 and glutathione transferase expression in human breast cancer. Clinical Cancer Research 9 705-709.

Eneman JD, Wood ME \& Muss HB 2004 Selecting adjuvant endocrine therapy for breast cancer. Oncology 18 1733-1744, discussion 1744-1745, 1748, 1751-1754.

Esteban JM, Warsi Z, Haniu M, Hall P, Shively JE \& Chen S 1992 Detection of intratumoral aromatase in breast carcinomas. An immunohistochemical study with clinicopathologic correlation. American Journal of Pathology 140 337-343.

Evans TR, Rowlands MG, Law M \& Coombes RC 1994 Intratumoral oestrone sulphatase activity as a prognostic marker in human breast carcinoma. British Journal of Cancer $69555-561$.

Falany JL \& Falany CN 1996 Expression of cytosolic sulfotransferases in normal mammary epithelial cells and breast cancer cell lines. Cancer Research $\mathbf{5 6}$ 1551-1555.

Falany CN, Krasnykh V \& Falany JL 1995 Bacterial expression and characterization of a cDNA for human liver estrogen sulfotransferase. Journal of Steroid Biochemistry and Molecular Biology 52 529-539.

Falany JL, Macrina N \& Falany CN 2002 Regulation of MCF-7 breast cancer cell growth by beta-estradiol sulfation. Breast Cancer Research and Treatment $\mathbf{7 4}$ 167-176.

Frasor J, Danes JM, Komm B, Chang KC, Lyttle CR \& Katzenellenbogen BS 2003 Profiling of estrogen up- and down-regulated gene expression in human breast cancer cells: insights into gene networks and pathways underlying estrogenic control of proliferation and cell phenotype. Endocrinology 144 4562-4574. 
Galant C, Gala JL, Van Den Berge V, Berliere M, Haumont E \& Horsmans Y 2001 Immunolocalisation of cytochrome P-450 3A enzymes in human breast carcinoma: relationship with tumour differentiation and steroid receptors. Pharmacology and Toxicology $\mathbf{8 8}$ 142-146.

Geissler WM, Davis DL, Wu L, Bradshaw KD, Patel S, Mendonca BB, Elliston KO, Wilson JD, Russell DW \& Andersson S 1994 Male pseudohermaphroditism caused by mutations of testicular 17beta-hydroxysteroid dehydrogenase 3. Nature Genetics 7 34-39.

Gingras S, Moriggl R, Groner B \& Simard J 1999 Induction of 3beta-hydroxysteroid dehydrogenase/delta5-delta4 isomerase type 1 gene transcription in human breast cancer cell lines and in normal mammary epithelial cells by interleukin-4 and interleukin-13. Molecular Endocrinology 13 66-81.

Gingras S, Cote S \& Simard J 2000 Multiple signaling pathways mediate interleukin-4-induced 3betahydroxysteroid dehydrogenase/delta5-delta4 isomerase type 1 gene expression in human breast cancer cells. Molecular Endocrinology 14 229-240.

Goss PE, Ingle JN, Martino S, Robert NJ, Muss HB, Piccart MJ, Castiglione M, Tu D, Shepherd LE, Pritchard KI, Livingston RB, Davidson NE, Norton L, Perez EA, Abrams JS, Therasse P, Palmer MJ \& Pater JL 2003 A randomized trial of letrozole in postmenopausal women after five years of tamoxifen therapy for earlystage breast cancer. New England Journal of Medicine 349 1793-1802.

Greeve MA, Allan RK, Harvey JM \& Bentel JM 2004 Inhibition of MCF-7 breast cancer cell proliferation by 5alpha-dihydrotestosterone; a role for p21(Cip1/Waf1). Journal of Molecular Endocrinology 32 793-810.

Gunasegaram R, Peh KL, Loganath A \& Ratnam SS 1998 Expression of 3beta-hydroxysteroid dehydrogenase-5,4-en isomerase activity by infiltrating ductal human breast carcinoma in vitro. Breast Cancer Research and Treatment 50 117-123.

Gunnarsson C, Olsson BM \& Stal O and the Southeast Sweden Breast Cancer Group 2001 Abnormal expression of 17beta-hydroxysteroid dehydrogenases in breast cancer predicts late recurrence. Cancer Research $\mathbf{6 1}$ 8448-8451.

Gunnarsson C, Ahnstrom M, Kirschner K, Olsson B, Nordenskjold B, Rutqvist LE, Skoog L \& Stal O 2003 Amplification of HSD17B1 and ERBB2 in primary breast cancer. Oncogene 22 34-40.

Hellmold H, Rylander T, Magnusson M, Reihner E, Warner M \& Gustafsson JA 1998 Characterization of cytochrome P450 enzymes in human breast tissue from reduction mammaplasties. Journal of Clinical Endocrinology and Metabolism 83 886-895.

Howell A, Cuzick J, Baum M, Buzdar A, Dowsett M, Forbes JF, Hoctin-Boes G, Houghton J, Locker GY \& Tobias and the ATAC Trialists' Group 2005 Results of the ATAC (Arimidex, Tamoxifen, Alone or in
Combination) trial after completion of 5 years' adjuvant treatment for breast cancer. Lancet 365 60-62.

Huang Z, Fasco MJ, Figge HL, Keyomarsi K \& Kaminsky LS 1996 Expression of cytochromes P450 in human breast tissue and tumors. Drug Metabolism and Disposition: the biological fate of chemicals 24 899-905.

Iscan M, Klaavuniemi T, Coban T, Kapucuoglu N, Pelkonen O \& Raunio H 2001 The expression of cytochrome P450 enzymes in human breast tumours and normal breast tissue. Breast Cancer Research and Treatment 70 47-54.

Isola JJ 1993 Immunohistochemical demonstration of androgen receptor in breast cancer and its relationship to other prognostic factors. Journal of Pathology 170 31-35.

Ji Q, Aoyama C, Nien YD, Liu PI, Chen PK, Chang L, Stanczyk FZ \& Stolz A 2004 Selective loss of AKR1C1 and AKR1C2 in breast cancer and their potential effect on progesterone signaling. Cancer Research 64 7610-7617.

Jin Y \& Penning TM 2001 Steroid 5alpha-reductases and 3alpha-hydroxysteroid dehydrogenases: key enzymes in androgen metabolism. Best Practices and Research in Clinical Endocrinology and Metabolism 15 79-94.

de Jong PC, Blankenstein MA, van de Ven J, Nortier JW, Blijham GH \& Thijssen JH 2001 Importance of local aromatase activity in hormone-dependent breast cancer: a review. Breast 10 91-99.

Kapucuoglu N, Coban T, Raunio H, Pelkonen O, Edwards RJ, Boobis AR \& Iscan M 2003 Expression of CYP3A4 in human breast tumour and non-tumour tissues. Cancer Letters 202 17-23.

Kauraniemi P, Barlund M, Monni O \& Kallioniemi A 2001 New amplified and highly expressed genes discovered in the ERBB2 amplicon in breast cancer by cDNA microarrays. Cancer Research 61 8235-8240.

Kinoshita Y \& Chen S 2003 Induction of aromatase (CYP19) expression in breast cancer cells through a nongenomic action of estrogen receptor alpha. Cancer Research 63 3546-3555.

Kristensen VN \& Borresen-Dale AL 2000 Molecular epidemiology of breast cancer: genetic variation in steroid hormone metabolism. Mutation Research 462 323-333.

Labrie F, Luu-The V, Labrie C, Belanger A, Simard J, Lin SX \& Pelletier G 2003 Endocrine and intracrine sources of androgens in women: inhibition of breast cancer and other roles of androgens and their precursor dehydroepiandrosterone. Endocrine Reviews 24 152-182.

Lapointe J \& Labrie C 2001 Role of the cyclin-dependent kinase inhibitor p27(Kip1) in androgen-induced inhibition of CAMA-1 breast cancer cell proliferation. Endocrinology 142 4331-4338.

Leers-Sucheta S, Morohashi K, Mason JI \& Melner MH 1997 Synergistic activation of the human type II 3beta-hydroxysteroid dehydrogenase/delta5-delta4 isomerase promoter by the transcription factor steroidogenic factor-1/adrenal 4-binding protein and 
phorbol ester. Journal of Biological Chemistry 272 7960-7967.

Lewis MJ, Wiebe JP \& Heathcote JG 2004 Expression of progesterone metabolizing enzyme genes (AKR1C1, AKR1C2, AKR1C3, SRD5A1, SRD5A2) is altered in human breast carcinoma. BMC Cancer 427.

Liehr JG 2000 Is estradiol a genotoxic mutagenic carcinogen? Endocrine Reviews 21 40-54.

Lipton A, Santen RJ, Santner SJ, Harvey HA, Sanders SI \& Matthews YL 1992 Prognostic value of breast cancer aromatase. Cancer 70 1951-1955.

Lu Q, Nakmura J, Savinov A, Yue W, Weisz J, Dabbs DJ, Wolz G \& Brodie A 1996 Expression of aromatase protein and messenger ribonucleic acid in tumor epithelial cells and evidence of functional significance of locally produced estrogen in human breast cancers. Endocrinology 137 3061-3068.

Luu-The V, Labrie C, Zhao HF, Couet J, Lachance Y, Simard J, Leblanc G, Cote J, Berube D, Gagne R \& Labrie F 1989 Characterization of cDNAs for human estradiol 17beta-dehydrogenase and assignment of the gene to chromosome 17: evidence of two mRNA species with distinct $5^{\prime}$-termini in human placenta. Molecular Endocrinology 3 1301-1309.

Luu-The V, Dufort I, Pelletier G \& Labrie F 2001 Type 5 17beta-hydroxysteroid dehydrogenase: its role in the formation of androgens in women. Molecular and Cellular Endocrinology 171 77-82.

McFadyen MC, Breeman S, Payne S, Stirk C, Miller ID, Melvin WT \& Murray GI 1999 Immunohistochemical localization of cytochrome P450 CYP1B1 in breast cancer with monoclonal antibodies specific for CYP1B1. Journal of Histochemistry and Cytochemistry 47 1457-1464.

MacIndoe JH \& Woods GR 1981 Steroid-metabolizing enzymes in human breast cancer cells. II. 5Alphareductase, 3alpha-hydroxysteroid oxidoreductase, and 17beta-hydroxysteroid oxidoreductase. Endocrinology 108 1407-1413.

Masuyama H, Hiramatsu Y, Kodama J \& Kudo T 2003 Expression and potential roles of pregnane $\mathrm{X}$ receptor in endometrial cancer. Journal of Clinical Endocrinology and Metabolism 88 4446-4454.

Masuyama H, Suwaki N, Tateishi Y, Nakatsukasa H, Segawa T \& Hiramatsu Y 2005 The pregnane X receptor regulates gene expression in a ligand- and promoter-selective fashion. Molecular Endocrinology 19 $1170-1180$.

Miettinen M, Mustonen M, Poutanen M, Isomaa V, Wickman M, Soderqvist G, Vihko R \& Vihko P 1999 17Beta-hydroxysteroid dehydrogenases in normal human mammary epithelial cells and breast tissue. Breast Cancer Research and Treatment 57 175-182.

Milewich L, Shaw CE, Doody KM, Rainey WE, Mason JI \& Carr BR 1991 3Beta-hydroxysteroid dehydrogenase activity in glandular and extraglandular human fetal tissues. Journal of Clinical Endocrinology and Metabolism 73 1134-1140.
Miller WR 1991 Aromatase activity in breast tissue. Journal of Steroid Biochemistry and Molecular Biology 39 783-790.

Miller WR \& O’Neill J 1987 The importance of local synthesis of estrogen within the breast. Steroids $\mathbf{5 0}$ 537-548.

Miller WR, Anderson TJ \& Jack WJ 1990 Relationship between tumour aromatase activity, tumour characteristics and response to therapy. Journal of Steroid Biochemistry and Molecular Biology 37 1055-1059.

Miller WR, Anderson TJ, Evans DB, Krause A, Hampton G \& Dixon JM 2003 An integrated view of aromatase and its inhibition. Journal of Steroid Biochemistry and Molecular Biology 86 413-421.

Miyoshi Y, Ando A, Shiba E, Taguchi T, Tamaki Y \& Noguchi S 2001 Involvement of up-regulation of 17beta-hydroxysteroid dehydrogenase type 1 in maintenance of intratumoral high estradiol levels in postmenopausal breast cancers. International Journal of Cancer 94 685-689.

Miyoshi Y, Ando A, Hasegawa S, Ishitobi M, Taguchi T, Tamaki Y \& Noguchi S 2003 High expression of steroid sulfatase mRNA predicts poor prognosis in patients with estrogen receptor-positive breast cancer. Clinical Cancer Research 9 2288-2293.

Modugno F, Knoll C, Kanbour-Shakir A \& Romkes M 2003 A potential role for the estrogen-metabolizing cytochrome P450 enzymes in human breast carcinogenesis. Breast Cancer Research and Treatment 82 191-197.

Newman SP, Purohit A, Ghilchik MW, Potter BV \& Reed MJ 2000 Regulation of steroid sulphatase expression and activity in breast cancer. Journal of Steroid Biochemistry and Molecular Biology 75 259-264.

Nussbaumer P \& Billich A 2004 Steroid sulfatase inhibitors. Medical Research Reviews 24 529-576.

Ortmann J, Prifti S, Bohlmann MK, Rehberger-Schneider S, Strowitzki T \& Rabe T 2002 Testosterone and 5alphadihydrotestosterone inhibit in vitro growth of human breast cancer cell lines. Gynecology and Endocrinology 16 $113-120$.

Osborne CK, Bardou V, Hopp TA, Chamness GC, Hilsenbeck SG, Fuqua SA, Wong J, Allred DC, Clark GM \& Schiff R 2003 Role of the estrogen receptor coactivator AIB1 (SRC-3) and HER-2/neu in tamoxifen resistance in breast cancer. Journal of the National Cancer Institute 95 353-361.

Osborne CK, Shou J, Massarweh S \& Schiff R 2005 Crosstalk between estrogen receptor and growth factor receptor pathways as a cause for endocrine therapy resistance in breast cancer. Clinical Cancer Research 11 $865 \mathrm{~s}-870 \mathrm{~s}$.

Oyama T, Morita M, Isse T, Kagawa N, Nakata S, So T, Mizukami M, Ichiki Y, Ono K, Sugaya M, Uramoto H, Yoshimatsu T, Hanagiri T, Sugio K, Kawamoto T \& Yasumoto K 2005 Immunohistochemical evaluation of cytochrome P450 (CYP) and p53 in breast cancer. Frontiers in Bioscience 10 1156-1161. 
Parker KL \& Schimmer BP 1997 Steroidogenic factor 1: a key determinant of endocrine development and function. Endocrine Reviews 18 361-377.

Pasqualini JR 2003 Differential effects of progestins on breast tissue enzymes. Maturitas 46 S45-S54.

Pasqualini JR 2004 The selective estrogen enzyme modulators in breast cancer: a review. Biochimica et Biophysica Acta 1654 123-143.

Pasqualini JR \& Chetrite GS 2005 Recent insight on the control of enzymes involved in estrogen formation and transformation in human breast cancer. Journal of Steroid Biochemistry and Molecular Biology 93 221-236.

Pasqualini JR, Maloche C, Maroni M \& Chetrite G 1994 Effect of the progestagen promegestone (R-5020) on mRNA of the oestrone sulphatase in the MCF-7 human mammary cancer cells. Anticancer Research 14 1589-1593.

Pasqualini JR, Chetrite G, Blacker C, Feinstein MC, Delalonde L, Talbi M \& Maloche C 1996 Concentrations of estrone, estradiol, and estrone sulfate and evaluation of sulfatase and aromatase activities in pre- and postmenopausal breast cancer patients. Journal of Clinical Endocrinology and Metabolism 81 1460-1464.

Pelletier G, Luu-The V, Tetu B \& Labrie F 1999 Immunocytochemical localization of type 517 betahydroxysteroid dehydrogenase in human reproductive tissues. Journal of Histochemistry and Cytochemistry 47 731-738.

Peltoketo H, Isomaa V, Maentausta O \& Vihko R 1998 Complete amino acid sequence of human placental 17beta-hydroxysteroid dehydrogenase deduced from cDNA. FEBS Letters 239 73-77.

Penning TM, Burczynski ME, Jez JM, Lin HK, Ma H, Moore M, Ratnam K \& Palackal N 2001 Structure function aspects and inhibitor design of type 5 17beta-hydroxysteroid dehydrogenase (AKR1C3). Molecular and Cellular Endocrinology 171 137-149.

Poirier D 2003 Inhibitors of 17beta-hydroxysteroid dehydrogenases. Current Medical Chemistry 10 453-477.

Poutanen M, Isomaa V, Lehto VP \& Vihko R $1992 a$ Immunohistochemical analysis of $17 \beta$-hydroxysteroid dehydrogenase in benign and malignant human breast tissue. International Journal of Cancer 50 386-390.

Poutanen M, Moncharmont B \& Vihko R $1992 b$ 17-Hydroxysteroid dehydrogenase gene expression in human breast cancer cells: regulation of expression by a progestin. Cancer Research 52 290-294.

Purohit A, Ghilchik MW, Duncan L, Wang DY, Singh A, Walker MM \& Reed MJ 1995 Aromatase activity and interleukin-6 production by normal and malignant breast tissues. Journal of Clinical Endocrinology and Metabolism 80 3052-3058.

Purohit A, Newman SP \& Reed MJ 2002 The role of cytokines in regulating estrogen synthesis: implications for the etiology of breast cancer. Breast Cancer Research 4 65-69.
Qian Y, Deng C \& Song WC 1998 Expression of estrogen sulfotransferase in MCF-7 cells by cDNA transfection suppresses the estrogen response: potential role of the enzyme in regulating estrogen-dependent growth of breast epithelial cells. Journal of Pharmacology and Experimental Therapeutics 286 555-560.

Qiu W, Campbell RL, Gangloff A, Dupuis P, Boivin RP, Tremblay MR, Poirier D \& Lin SX 2002 A concerted, rational design of type 1 17beta-hydroxysteroid dehydrogenase inhibitors: estradiol-adenosine hybrids with high affinity. FASEB Journal 16 1829-1831.

Raunio H, Hakkola J \& Pelkonen O 2005 Regulation of CYP3A genes in the human respiratory tract. Chemico-biological Interactactions 151 53-62.

Recchione C, Venturelli E, Manzari A, Cavalleri A, Martinetti A \& Secreto G 1995 Testosterone, dihydrotestosterone and oestradiol levels in postmenopausal breast cancer tissues. Journal of Steroid Biochemistry and Molecular Biology 52 541-546.

Reed MJ \& Purohit A 2001 Aromatase regulation and breast cancer. Clinical Endocrinology 54 563-571.

Reed MJ, Rea D, Duncan LJ \& Parker MG 1994 Regulation of estradiol 17beta-hydroxysteroid dehydrogenase expression and activity by retinoic acid in T47D breast cancer cells. Endocrinology 135 4-9.

Reed MJ, Purohit A, Woo LW, Newman SP \& Potter BV 2005 Steroid sulfatase: molecular biology, regulation, and inhibition. Endocrine Reviews 26 171-202.

Rheaume E, Lachance Y, Zhao HF, Breton N, Dumont M, de Launoit Y, Trudel C, Luu-The V, Simard J \& Labrie F 1991 Structure and expression of a new complementary DNA encoding the almost exclusive 3beta-hydroxysteroid dehydrogenase/delta 5-delta 4-isomerase in human adrenals and gonads. Molecular Endocrinology $\mathbf{5}$ 1147-1157.

Robertson JF \& Blamey RW 2003 The use of gonadotrophinreleasing hormone $(\mathrm{GnRH})$ agonists in early and advanced breast cancer in pre- and perimenopausal women. European Journal of Cancer 39 861-869.

Russell DW \& Wilson JD 1994 Steroid 5alpha-reductase: two genes/two enzymes. Annual Review of Biochemistry 63 25-61.

Saeki T, Takashima S, Sasaki H, Hanai N \& Salomon DS 1999 Localization of estrone sulfatase in human breast carcinomas. Breast Cancer 6 331-337.

Sakamoto H, Utsumi T, Honda S, Yoshimura N, Sasaki E \& Harada N 2002 The intraclinological estrogen metabolism in breast cancer cell lines. Program of the 6th International Aromatase Conference, Kyoto, Japan, p 113 (Abstract P 6-2).

Santen RJ, Martel J, Hoagland M, Naftolin F, Roa L, Harada N, Hafer L, Zaino R \& Santner SJ 1994 Stromal spindle cells contain aromatase in human breast tumors. Journal of Clinical Endocrinology and Metabolism 79 627-632. 
Santner SJ, Feil PD \& Santen RJ 1984 In situ estrogen production via the estrone sulfatase pathway in breast tumors: relative importance versus the aromatase pathway. Journal of Clinical Endocrinology and Metabolism 59 29-33.

Sasano H \& Harada N 1998 Intratumoral aromatase in human breast, endometrial, and ovarian malignancies. Endocrine Reviews 19 593-607.

Sasano H, Nagura H, Harada N, Goukon Y \& Kimura M 1994 Immunolocalization of aromatase and other steroidogenic enzymes in human breast disorders. Human Pathology 5 530-533.

Sasano H, Frost AR, Saitoh R, Harada N, Poutanen M, Vihko R, Bulun SE, Silverberg SG \& Nagura H 1996 Aromatase and 17 $\beta$-hydroxysteroid dehydrogenase type 1 in human breast carcinoma. Journal of Clinical Endocrinology and Metabolism 81 4042-4046.

Sasano H, Edwards DP, Anderson TJ, Silverberg SG, Evans DB, Santen RJ, Ramage P, Simpson ER, Bhatnagar AS \& Miller WR 2003 Validation of new aromatase monoclonal antibodies for immunohistochemistry: progress report. Journal of Steroid Biochemistry and Molecular Biology 86 239-244.

Sebastian S, Takayama K, Shozu M \& Bulun SE 2002 Cloning and characterization of a novel endothelial promoter of the human CYP19 (aromatase P450) gene that is up-regulated in breast cancer tissue. Molecular Endocrinology 16 2243-2254.

Shenton KC, Dowsett M, Lu Q, Brodie A, Sasano H, Sacks NP \& Rowlands MG 1998 Comparison of biochemical aromatase activity with aromatase immunohistochemistry in human breast carcinomas. Breast Cancer Research and Treatment 49 S101-S107; discussion S109-S119.

Silva MC, Rowlands MG, Dowsett M, Gusterson B, McKinna JA, Fryatt I \& Coombes RC 1989 Intratumoral aromatase as a prognostic factor in human breast carcinoma. Cancer Research 49 2588-2591.

Simard J \& Gingras S 2001 Crucial role of cytokines in sex steroid formation in normal and tumoral tissues. Molecular and Cellular Endocrinology 171 25-40.

Simpson ER \& Davis SR 2001 Minireview: aromatase and the regulation of estrogen biosynthesis - some new perspectives. Endocrinology 142 4589-4594.

Singh A, Purohit A, Ghilchik MW \& Reed MJ 1999 The regulation of aromatase activity in breast fibroblasts: the role of interleukin- 6 and prostaglandin $E_{2}$. Endocrine-Related Cancer 6 139-147.

Sirianni R, Seely JB, Attia G, Stocco DM, Carr BR, Pezzi V \& Rainey WE 2002 Liver receptor homologue-1 is expressed in human steroidogenic tissues and activates transcription of genes encoding steroidogenic enzymes. Journal of Endocrinology 174 R13-R17.

Somboonporn W \& Davis SR and the National Health and Medical Research Council 2004 Testosterone effects on the breast: implications for testosterone therapy for women. Endocrine Reviews 25 374-388.
Sonne-Hansen K \& Lykkesfeldt AE 2005 Endogenous aromatization of testosterone results in growth stimulation of the human MCF-7 breast cancer cell line. Journal of Steroid Biochemistry and Molecular Biology 93 25-34.

Speirs V, Green AR, Walton DS, Kerin MJ, Fox JN, Carleton PJ, Desai SB \& Atkin SL 1998 Short-term primary culture of epithelial cells derived from human breast tumours. British Journal of Cancer $\mathbf{7 8}$ 1421-1429.

Spink BC, Katz BH, Hussain MM, Pang S, Connor SP, Aldous KM, Gierthy JF \& Spink DC 2000 SULT1A1 catalyzes 2-methoxyestradiol sulfonation in MCF-7 breast cancer cells. Carcinogenesis 21 1947-1957.

Surmacz E \& Bartucci M 2004 Role of estrogen receptor alpha in modulating IGF-I receptor signaling and function in breast cancer. Journal of Experimental Clinical Cancer Research 23 385-394.

Suzuki T, Moriya T, Ariga N, Kaneko C, Kanazawa M \& Sasano H 2000a 17Beta-hydroxysteroid dehydrogenase type 1 and type 2 in human breast carcinoma: a correlation to clinicopathological parameters. British Journal of Cancer 82 518-523.

Suzuki T, Sasano H, Andersson S \& Mason JI $2000 b$ 3Beta-hydroxysteroid dehydrogenase/delta5->4isomerase activity associated with the human 17beta-hydroxysteroid dehydrogenase type 2 isoform. Journal of Clinical Endocrinology and Metabolism $\mathbf{8 5}$ 3669-3672.

Suzuki T, Darnel AD, Akahira JI, Ariga N, Ogawa S, Kaneko C, Takeyama J, Moriya T \& Sasano H 2001 a 5Alpha-reductases in human breast carcinoma: possible modulator of in situ androgenic actions. Journal of Clinical Endocrinology and Metabolism 86 2250-2257.

Suzuki T, Moriya T, Sugawara A, Ariga N, Takabayashi H \& Sasano H $2001 b$ Retinoid receptors in human breast carcinoma: possible modulators of in situ estrogen metabolism. Breast Cancer Research and Treatment $\mathbf{6 5}$ 31-40.

Suzuki T, Murry BA, Darnel AD \& Sasano H 2002 Progesterone metabolism in human leukemic monoblast U937 cells. Endocrine Journal 49 539-546.

Suzuki T, Nakata T, Miki Y, Kaneko C, Moriya T, Ishida T, Akinaga S, Hirakawa H, Kimura M \& Sasano H 2003 Estrogen sulfotransferase and steroid sulfatase in human breast carcinoma. Cancer Research 63 2762-2770.

Suzuki T, Miki Y, Moriya T, Shimada N, Ishida T, Hirakawa H, Ohuchi N \& Sasano H 2004 Estrogenrelated receptor alpha in human breast carcinoma as a potent prognostic factor. Cancer Research 64 4670-4676.

Tremblay Y \& Beaudoin C 1993 Regulation of 3beta-hydroxysteroid dehydrogenase and 17betahydroxysteroid dehydrogenase messenger ribonucleic acid levels by cyclic adenosine $3^{\prime}, 5^{\prime}$-monophosphate and phorbol myristate acetate in human choriocarcinoma cells. Molecular Endocrinology 7 355-364. 
Tseng L, Mazella J, Lee LY \& Stone ML 1983 Estrogen sulfatase and estrogen sulfotransferase in human primary mammary carcinoma. Journal of Steroid Biochemistry 4 1413-1417.

Tsuchiya Y, Nakajima M, Kyo S, Kanaya T, Inoue M \& Yokoi T 2004 Human CYP1B1 is regulated by estradiol via estrogen receptor. Cancer Research 64 3119-3125.

Utsumi T, Harada N, Maruta M \& Takagi Y 1996 Presence of alternatively spliced transcripts of aromatase gene in human breast cancer. Journal of Clinical Endocrinology and Metabolism 81 2344-2349.

Utsumi T, Yoshimura N, Takeuchi S, Ando J, Maruta M, Maeda K \& Harada N 1999 Steroid sulfatase expression is an independent predictor of recurrence in human breast cancer. Cancer Research 59 377-381.

Vihko P, Herrala A, Harkonen P, Isomaa V, Kaija H, Kurkela R, Li Y, Patrikainen L, Pulkka A, Soronen P \& Torn S 2005 Enzymes as modulators in malignant transformation. Journal of Steroid Biochemistry and Molecular Biology 93 277-283.

Wiebe JP, Muzia D, Hu J, Szwajcer D, Hill SA \& Seachrist JL 2000 The 4-pregnene and 5alpha-pregnane progesterone metabolites formed in nontumorous and tumorous breast tissue have opposite effects on breast cell proliferation and adhesion. Cancer Research $\mathbf{6 0}$ 936-943.

Wiebe JP, Lewis MJ, Cialacu V, Pawlak KJ \& Zhang G 2005 The role of progesterone metabolites in breast cancer: potential for new diagnostics and therapeutics. Journal of Steroid Biochemistry and Molecular Biology 93 201-208.

Wu L, Einstein M, Geissler WM, Chan HK, Ellison KO \& Andersson S 1993 Expression cloning and characterization of human $17 \beta$-hydroxysteroid dehydrogenase type 2 , a microsomal enzyme possessing
$20 \alpha$-hydroxysteroid dehydrogenase activity. Journal of Biological Chemistry 168 12964-12969.

Yamaguchi Y, Takei H, Suemasu K, Kobayashi Y, Kurosumi M, Harada N \& Hayashi S 2005 Tumorstromal interaction through the estrogen-signaling pathway in human breast cancer. Cancer Research $\mathbf{6 5}$ 4653-4662.

Yamamoto Y, Yamashita J, Toi M, Muta M, Nagai S, Hanai N, Furuya A, Osawa Y, Saji S \& Ogawa M 2003 Immunohistochemical analysis of estrone sulfatase and aromatase in human breast cancer tissues. Oncology Reports 10 791-796.

Yang C, Zhou D \& Chen S 1998 Modulation of aromatase expression in the breast tissue by ERR alpha-1 orphan receptor. Cancer Research 58 5695-5700.

Yoshimura N, Harada N, Bukholm I, Karesen R, BorresenDale AL \& Kristensen VN 2004 Intratumoural mRNA expression of genes from the oestradiol metabolic pathway and clinical and histopathological parameters of breast cancer. Breast Cancer Research 6 R46-R55.

Zhao Y, Agarwal VR, Mendelson CR \& Simpson ER 1996 Estrogen biosynthesis proximal to a breast tumor is stimulated by $\mathrm{PGE}_{2}$ via cyclic AMP, leading to activation of promoter II of the CYP19 (aromatase) gene. Endocrinology 137 5739-5742.

Zhou J, Gurates B, Yang S, Sebastian S \& Bulun SE 2001 Malignant breast epithelial cells stimulate aromatase expression via promoter II in human adipose fibroblasts: an epithelial-stromal interaction in breast tumors mediated by CCAAT/enhancer binding protein beta. Cancer Research 61 2328-2334.

Zhou J, Suzuki T, Kovacic A, Saito R, Miki Y, Ishida T, Moriya T, Simpson ER, Sasano H \& Clyne CD 2005 Interactions between prostaglandin $\mathrm{E}_{2}$, liver receptor homologue-1, and aromatase in breast cancer. Cancer Research 65 657-663. 